\title{
Stratigraphy of the
}

Cambrian and Ordovician

\section{Rocks of East-Central}

Alaska

GEOLOGICAL SURVEY PROFESSIONAL PAPER 559-A

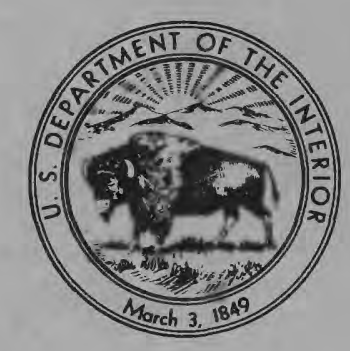




\section{Stratigraphy of the}

\section{Cambrian and Ordovician}

\section{Rocks of East-Central}

\section{Alaska}

By EARL E. BRABB

LOWER PALEOZOIC PALEONTOLOGY AND STRATIGRAPHY OF EAST-CENTRAL ALASKA

GEOLOGICAL SURVEY PROFESSIONAL PAPER 559-A

Descriptions of four newly named formations of Early Cambrian to Middle Ordovician age, and their ecological implications; with a list of lower Paleozoic fossil collections

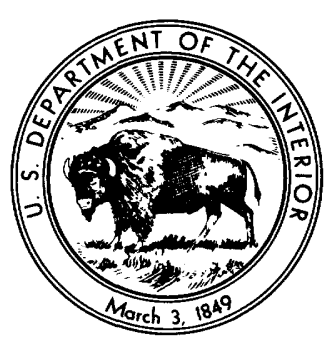




\section{UNITED STATES DEPARTMENT OF THE INTERIOR \\ STEWART L. UDALL, Secretary \\ GEOLOGIGAL SURVEY \\ William T. Pecora, Director}




\section{CONTENTS}

Abstract

Introduction

Precambrian rocks

Tindir Group

Cambrian rocks

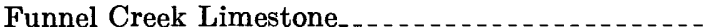

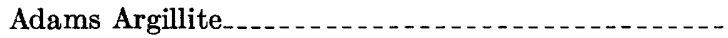

Cambrian and Ordovician rocks . . . . . . . . . . . . . .

Hillard Limestone . . . . . .

Jones Ridge Limestone. . . . . . . . . . . . . . . . .

Lower member . . . . . . . .

Upper member.

\begin{tabular}{r|} 
Page \\
A1 \\
1 \\
3 \\
3 \\
6 \\
6 \\
7 \\
9 \\
9 \\
15 \\
15 \\
18
\end{tabular}

Cambrian and Ordovician rocks-Continued

Unnamed chert, shale, and limestone _. _. _..... A19

Paleotectonic implications. . . . . . . . . . . . . . . . 19

Facies and their ecological implications

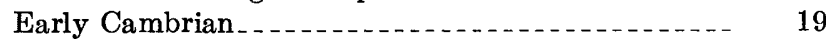

Middle Cambrian

Late Cambrian and Early Ordovician . . . . . . . . 21

Middle or Late Ordovician

Summary

Lower Paleozoic fossil collections from east-central Alaska

References cited

\section{ILLUSTRATIONS}

Figure 1. Map showing areas of Cambrian and Ordovician rocks in Alaska

2. Columnar sections $\ldots \ldots \ldots \ldots \ldots$

3. Locality map.

4-12. Photographs showing-

4. Lower Paleozoic sequence along Tatonduk River.

5. Cambrian sequence at east end of Limestone Hogback

6. Hillard Limestone near Hillard Peak . . .

7. Location of measured sections in Adams Peak-Yukon River area

8. Hillard Limestone and Adams Argillite near Adams Peak

9. Hillard Limestone on ridge and flatiron southwest of Adams Peak

10. Limestone edgewise conglomerate.

11. Limestone boulder conglomerate ledge along Tatonduk River

12. Contact between Jones Ridge Limestone and Tindir Group

13. Stratigraphic columns of lower Paleozoic formations in east-central Alaska.

14. Photograph showing upper part of Jones Ridge Limestone

15. Lithofacies maps, Early to Late Cambrian

16. Lithofacies maps, Late Cambrian to Middle or Late Ordovician. 



\title{
LOWER PALEOZOIC PALEONTOLOGY AN'n STRATIGRAPHY OF EAST-CENTRAL ALASKA
}

\section{STRATIGRAPHY OF THE GAMBRIAN AND ORDOVIGIAN ROGKS OF EAST-GENTRAL ALASKA}

\author{
By EarL E. BrabB
}

\begin{abstract}
Four new formational names are herein established for the westernmost known exposures of Cambrian sedimentary rocks in North America. The Funnel Creek Limestone and Adams Argillite of Early Cambrian age and the Hillard Limestone of Early Cambrian to Early Ordovician age are key formations in determining the structure and stratigraphy of the Hillard Peak to Hard Luck Creek area, and the largely coeval Jones Ridge Limestone of Early Cambrian to Middle or Late Ordovician age forms spectacular cliffs and jagged peaks in the Jones Ridge-Squaw Mountain area. Facies maps prepared from measured sections of these formations and from fossil determinations suggest that the Jones Ridge-Squaw Mountain area was some sort of shoal or reef during part of the early Paleozoic, and that the Hillard Peak-Hard Luck Creek area was a turbulent marine shelf that received considerable terrigenous material from unknown sources, and possibly some material from the Jones RidgeSquaw Mountain shoal.

The area was uplifted, very gently folded, and eroded during late Tremadocian or Arenigian (Early Ordovician) time. The fold axes apparently trended northeast. Deposition resumed in latest Arenigian or earliest Llanvirnian (Early Ordovician) time in part of the area, and in Caradocian or Ashgillian (Middle or Late Ordovician) time in the Jones Ridge-Squaw Mountain area.

The rapid changes in facies, the possibility of reeflike sedimentation, and the occurrence of bitumen and other organic matter in the rocks make the lower Paleozoic rocks attractive for petroleum exploration.
\end{abstract}

\section{INTRODUCTION}

Undoubted Cambrian fossils in Alaska have been found only in the vicinity of Eagle (fig. 1). The regional significance of the rocks containing these fossils rests largely on their unique geographic position as the westernmost known exposures of Cambrian sedimentary rocks in North America. The Cambrian section of the Eagle area provides a critical link between the Cambrian in southern parts of the Cordilleran geosyncline and that in various parts of Asia and the Arctic.

Fossils of definite Cambrian age in Alaska were first discovered by Cairnes (1914a) along the international boundary in the vicinity of Eagle. L. D. Burling identified the fossils for Cairnes and determined that faunas of Middle and Late Cambrian age are present. Cairnes did not map the Cambrian rocks separately but included them in an undivided limestone and dolomite unit of Cambrian to Devonian age. Mertie (1930) subdivided the rocks of Cambrian and possible Cambrian age into four unnamed formations plus the Tindir Group, and he (1933) proposed the following classification which until now has served as a standard:

1. Tindir Group of pre-Middle Cambrian age (probably Precambrian).

2. Lower plate of Middle Cambrian limestone.

3. A thin formation of slate and quartzite, also of Middle Cambrian age.

4. Upper plate of Middle Cambrian limestone.

5. Upper Cambrian limestone which grades upward without any noticeable straitigraphic or lithologic break into Ordovician limestone.

On his geologic map, Mertie (1933, pl. 7) shows an additional limestone unit of Late Cambrian age which, for purposes of discussion, is here designated unit 5A.

The fossils collected by Mertie were not referred to his map units but rather to series of the Cambrian, so the relative stratigraphic position of these collections is difficult to determine. For example, some of the archaeocyathids reported by Mertie are considered by Okulitch (1956, p. 725) to be of Early, not Middle, Cambrian age, but the relation of the rocks containing the archaeocyathids to rocks containing definite Middle Cambrian trilobites is uncertain. Moreover, there seems to be no lithologic means for distinguishing his units 2, 4,5 , and $5 \mathrm{~A}$. For these reasons, a new set of formations is established here on the basis of mapping of lithologically separable units containing stratigraphically oriented fossil collections.

The Cambrian rocks described in this report were first examined in 1960 as part of a project to prepare a regional geologic map $(1: 250,000)$ of the area between the Yukon and Porcupine Rivers and the U.S.-Canada border. Preliminary geologic maps of some of this area 


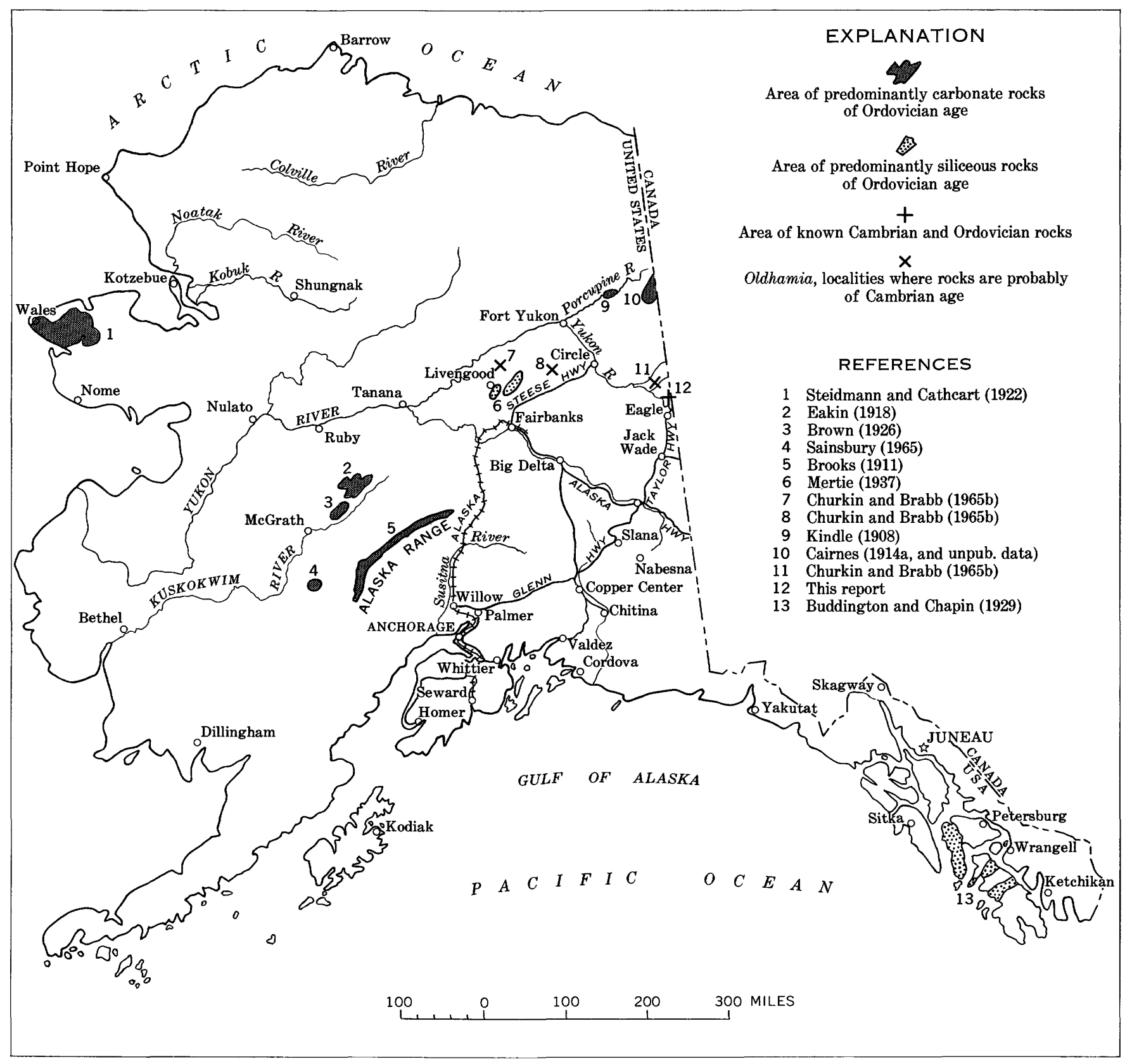

Figure 1.-Index map showing areas of Cambrian and Ordovician rocks in Alaska. Prepared by Michael Churkin, Jr. 
have been released as open-file reports of the U.S. Geological Survey (Brabb and Churkin, 1964, 1965). Approximately 4 days during the summer of 1960 and 6 days during 1961 were spent examining the Cambrian rocks and collecting fossils from them. R. N. Passero and H. J. Roepke in 1960 and J. C. Melik and R. L. Taylor in 1961 assisted in the geologic work. Michael Churkin, Jr., geologist, and A. J. Aadland, field assistant, joined the project in May, 1962. During the summer of 1962 transportation was to have been mainly by helicopter, but because of two crashes and other mechanical mishaps we spent only 3 days travelling by helicopter and boat and examining rocks of Cambrian age. R. J. Ross, Jr., and L. R. Mayo, of the U.S. Geological Survey, joined the field party for 11 days in July and spent about 3 of them examining and collecting Cambrian rocks near Jones Ridge. In July 1963, the author, Churkin, A. R. Palmer, and D. L. Giles, field assistant, spent 5 days examining Cambrian rocks along the Yukon and Tatonduk Rivers, using boat transportation, and about 6 days examining, measuring, and collecting Cambrian rocks at other localities, using a helicopter.

In total, therefore, less than a month was spent examining Cambrian rocks in an area of complex geology covering more than 70 square miles. Most of the sections were rather hurriedly measured and described, and the thickness of some was only visually estimated. The rock-stratigraphic classification is thought to be a substantial refinement of Mertie's (1933, p. 392) original contribution, but it has not been tested by extensive detailed mapping.

Geologists following in our footsteps may find an apparent lack of fossils in rocks where we made several collections. Many of our collections were from small lenses that we completely removed. In general, the fossils are in coarse-grained limestone, although several rich faunas are from fine-grained limestone. Hookshaped cross sections of trilobites, along weathered surfaces perpendicular to the bedding of the limestone, frequently led to the discovery of richly fossiliferous beds. All fossils are from rock in place unless otherwise noted.

All the ages of fossils and rocks in this report were determined by $\mathbf{A}$. R. Palmer, unless otherwise noted. Color terms are from the color chart of Goddard and others (1948).

\section{PRECAMBRIAN ROCKS}

\section{TINDIR GROUP}

A 5,000- to 25,000-foot-thick succession of limestone, dolomite, quartzite, shale, and greenstone along the Alaska-Yukon Territory boundary between the Yukon and Porcupine Rivers was named the Tindir Group by Cairnes (1914a). Mertie (1933) subdivided the Tindir Group into seven informal units, and the youngest of these, termed unit $\mathbf{A}$ by Mertie, is the oldest formation shown on the columnar sections (fig. 2).

Cairnes (1914a, p. 56) thought that the Tindir Group is either entirely of Precambrian age, or that it is Precambrian and Early Cambrian. Mertie (1933, p. 392) thought that the Tindir Group is probably Precambrian. Inasmuch as the oldest fossils they found stratigraphically above the Tindir Group were considered to be of Middle Cambrian age, all they could definitely state is that the Tindir Group is not younger than Middle Cambrian.

The oldest fossils collected stratigraphically above the Tindir Group during the present investigation are of Early Cambrian age, according to A. R. Palmer. The Tindir Group, therefore, is not younger than Early Cambrian.

The age of the Tindir Group is related to the worldwide Precambrian-Cambrian boundary problem. I agree with Okulitch (1956) that the beginning of Cambrian time should, on paleontologic grounds, coincide with the appearance of olenellid trilobites and (or) archaeocyathids and should, on stratigraphic grounds, be placed at some important discontinuity in the stratigraphic section. To compromise with the paleontologic approach, such a discontinuity should be as close as possible to, and below, the lowest Cambrian fossils. In this part of Alaska, the lowest Cambrian fossils, consisting of archaeocyathids, were found about 500 feet stratigraphically above the top of unit $\mathbf{A}$, the highest unit of the Tindir Group in the Jones RidgeSquaw Mountain area. No definite discontinuity has been recognized below these fossils, but there is an abrupt lithologic change from the dark platy limestone of unit $\boldsymbol{A}$ to the archaeocyathid-bearing white limestone and dolomite stratigraphically above the Tindir Group. The top of the Tindir Group is, therefore, provisionally and arbitrarily considered the top of the Precambrian in east-central Alaska. 


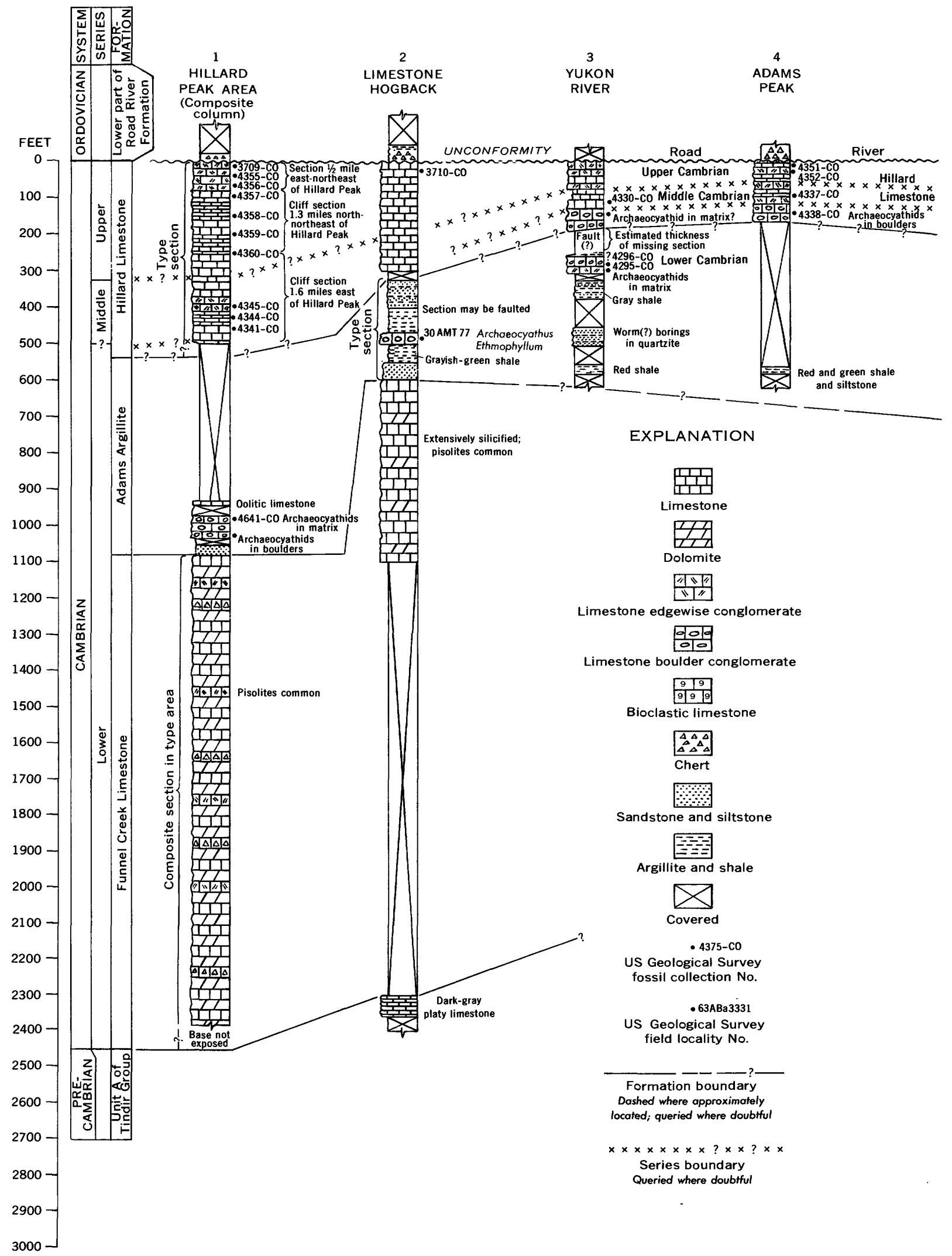

FIgURE 2.-Columnar sections of Cambrian and Ordovician 


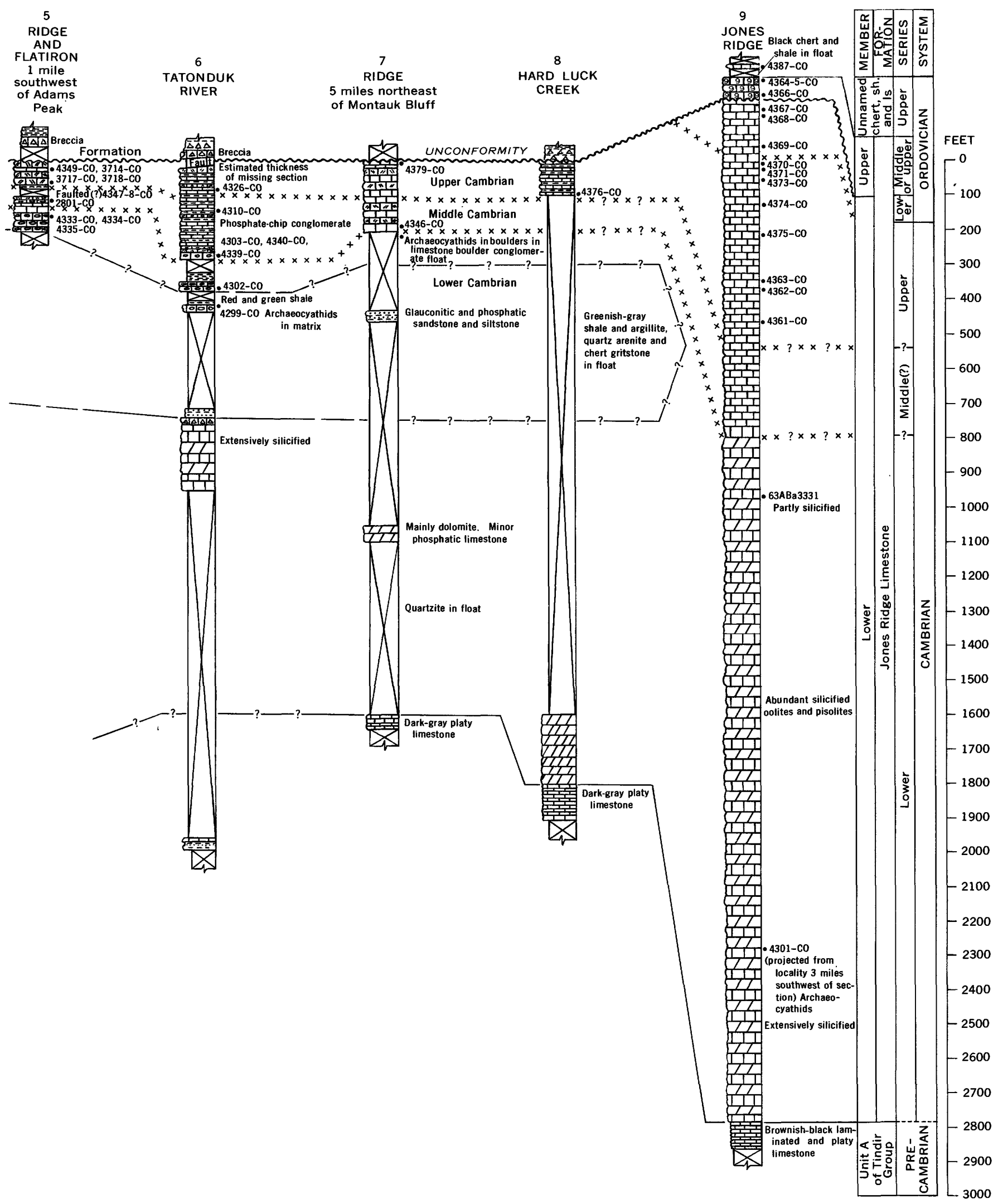

rocks of east-central Alaska. Locations are shown in figure 3. 
CAMBRIAN ROCKS

\section{FUNNEL CREER LIMESTONE}

A massive carbonate formation exposed in the vicinity of the Alaska-Yukon boundary between Funnel Creek and Hillard Peak and between the Tatonduk River, Hard Luck Creek, and Montauk Bluff (see fig.
3 for localities) has been variously treated. Cairnes (1914b) included it within his undifferentiated carbonate unit of Cambrian to Devonian age. Mertie (1933, pl. 7) included the formation (1) within his Upper Cambrian limestone (his unit 5A) about 1 mile east and northeast of Hillard Peak, (2) as limestone of Silurian age in the vicinity of Funnel Creek, (3) as his

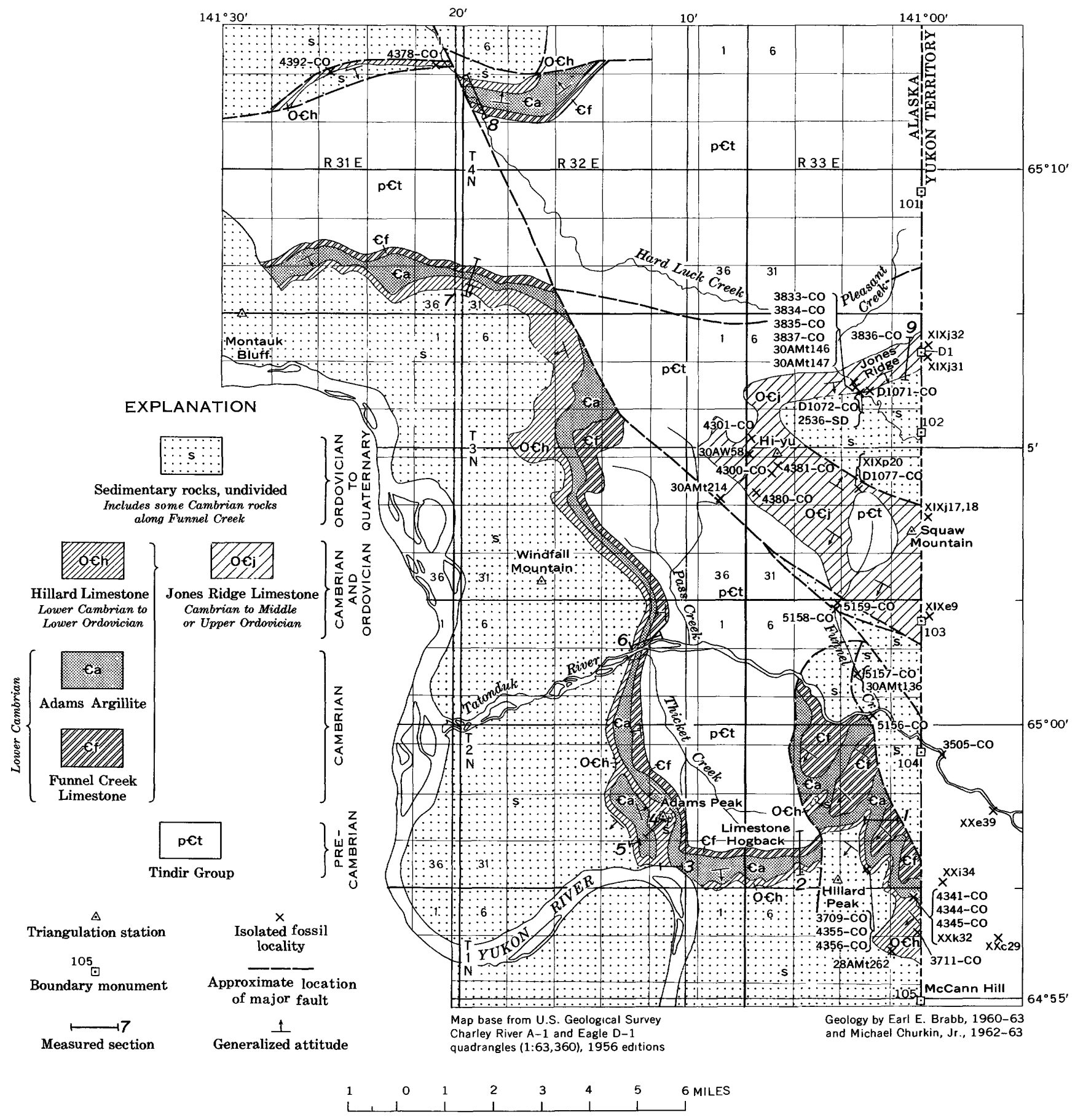

FIGURE 3.-Map showing location of sections and distribution of Cambrian and Ordovician formations. 
lower plate or part of his lower plate of Middle Cambrian limestone (his unit 4) from Limestone Hogback to the Tatonduk River, and (4) within the Tindir Group between Hard Luck Creek and Montauk Bluff. Green and Roddick (1962) mapped it in Canada within an unnamed limestone and dolomite formation (their unit 6a) of Early (?) Cambrian to Ordovician(?) and possibly of Precambrian age. Brabb and Churkin mapped it (1964) as an unnamed dolomite formation in the Charley River quadrangle $(1: 250,000)$ and $(1965)$ as unnamed limestone formation in the Eagle $\mathrm{D}-1$ quadrangle $(1: 63,360)$. It is here named the Funnel Creek Limestone for exposures 1-3 miles south and southwest of the mouth of Funnel Creek.

The Funnel Creek Limestone extends in a nearly continuous band from Hillard Peak to Montauk Bluff. It extends into the Yukon Territory for at least 10 miles and may be present but unrecognized in more northerly areas along the boundary of the Yukon Territory and Alaska.

The type area of the Funnel Creek Limestone includes the valley walls of three unnamed tributaries of the Tatonduk River from 1 mile southwest to 3 miles due south of the mouth of Funnel Creek, in sections 17, 20, 21, 27, and 28, T. 2 N., R. 33 E., where the formation forms craggy cliffs and scenic gorges. Information from the type area has been combined in the composite stratigraphic column (fig. 2, column 1).

The gross appearance of the Funnel Creek Limestone at a distance is massive, very light gray $(N 8)$ carbonate rock having relatively few widely spaced bedding-plane joints or parting surfaces. On close examination, however, some of the rock has pale-yellowish-brown (10YR $6 / 2$ ) laminations. Some of the rock is also oolitic limestone and edgewise conglomerate consisting of laminated slabs of limestone about 1 inch thick and 10 inches in maximum dimension, inclined at angles to the general bedding and cemented by calcite.

Almost all the Funnel Creek Limestone is carbonate rock, but not enough of the section has been examined to determine the proportion of limestone to dolomite. The formation seems to be predominantly limestone. There are a few thin interbeds of dark-gray chert. Secondary quartz replacing pisolites and oolites, chalcedony-lined vugs, and irregularly shaped siliceous veins in the limestone are common.

On the north valley slope of the Tatonduk River about three-quarters of a mile downstream from the mouth of Pass Creek, the Funnel Creek Limestone forms a prominent cliff (fig. 4). The rock there is predominantly massive light-gray $(N 7)$ medium-grained limestone that has been extensively silicified, dolomitized, and recrystallized. Some of the secondary calcite crys- tals are $10 \mathrm{~mm}$ long. There are a few dark-gray chert nodules and many oolites in the limestone. A black bituminous(?) mineral, possibly anthraxolite, is common along fractures and in the matrix of the limestone. The uppermost 15 feet of the formation along the river is a breccia consisting of angular grit and pebble-size fragments of limestone, dolomite, chert, and phosphate.

North of the Tatonduk River area, the Funnel Creek Limestone is mainly dolomite. Along the ridges northeast of Montauk Bluff the dolomite is very pale orange $(10 Y R 6 / 2)$ and has interbeds of dark-yellowish-brown $(10 Y R$ 4/2) fine-grained phosphate limestone. Near Hard Luck Creek the dolomite is yellowish gray ( $5 Y$ $8 / 1$ ).

The thickness of the Funnel Creek Limestone in its type area is not less than 1,300 feet, which is a partial thickness because the base of the formation is not exposed there. Along Limestone Hogback it seems much thinner, about 500 feet, but 1,200 feet of section below the lowest exposure of Funnel Creek Limestone and the highest exposure of the Tindir Group is covered. Similarly, in the Tatonduk River, Montauk Bluff, and Hard Luck Creek areas the Funnel Creek Limestone seems to be 50-200 feet thick, but most of the section in these areas is covered.

No fossils have been found in the Funnel Creek Limestone.

The contact of the Funnel Creek Limestone with the Tindir Group is only rarely exposed, but the units seem accordant throughout their known extent. Although no gradation or intercalations of lithologies were observed across the contact, there is no reason why the units cannot be conformable.

The Funnel Creek Limestone is overlain by a formation containing fossils of Early Cambrian age. Inasmuch as the top of the Tindir Group has been designated the top of the Precambrian, the Funnel Creek Limestone is herein considered to be of Early Cambrian age.

\section{ADAMS ARGILLITE}

Mertie (1933) recognized and mapped a "slate" and quartzite formation (his unit 3) between Hillard Peak and Adams Peak. The formation was extended in a continuous belt to the Montauk Bluff area by Brabb and Churkin (1964) and has been recognized by them in isolated patches as far west as the headwaters of the Black River, about 80 miles northwest of Adams Peak, a newly named mountain between the Tatonduk and Nation Rivers (fig. 3). The formation is here named the Adams Argillite for exposures in the vicinity of Adams Peak.

No complete section of the Adams Argillite has been found, but parts of it can be observed along the north 


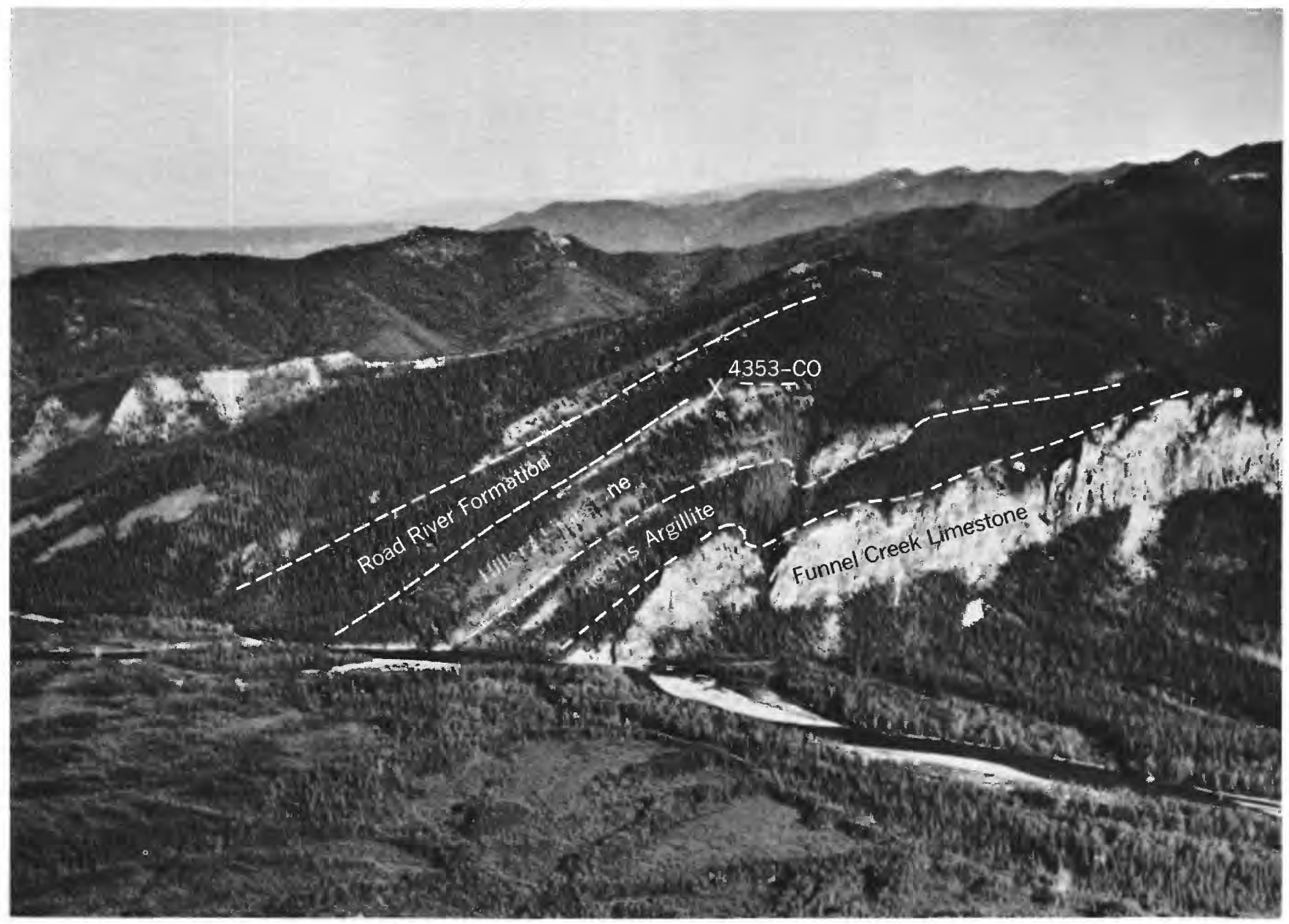

Figure 4.-Lower Paleozoie sequence in the Tatonduk River area showing prominent cliff of Funnel Creek Limestone in foreground and less conspicuous outcrops of overlying formations in middle background. The beds from which collection 4353-CO was obtained are thought to be faulted out at river level. View is northwest.

bank of the Yukon River about 1 mile south of Adams Peak; along a small north-trending ridge at the east end of Limestone Hogback, about 3 miles east-southeast of Adams Peak; at scattered localities 1-2 miles north and east of Hillard Peak; and along the north bank of the Tatonduk River about 3 miles north of Adams Peak. The section at the east end of Limestone Hogback (fig. 5) in the W1/2 sec. 31, T. 2 N., R. 33 E. seems to be most complete and is designated the type section. This section was not examined in detail and may be faulted. On figure 2, column 2 , it is shown diagrammatically.

The basal beds of the Adams Argillite are light-brown quartzite. Most of the quartzite is massive, but along the Tatonduk River it is thinly bedded and cross laminated and has interbeds of siltstone and grayish-green $(10 G Y 5 / 2)$ chloritic shale. The quartzite is wellsorted quartz arenite cemented by quartz and (or) carbonate.
A variety of rocks make up the rest of the Adams Argillite. The argillaceous rocks include gray, green, and red argillate and shale. Light-olive-gray ( $5 Y 5 / 2)$ argillate and interbeds of laminated quartzite and siltstone are characteristic of the formation between Hard Luck Creek and the Kandik River and may be the predominant lithology in its largely covered parts in the area between Hard Luck Creek and Hillard Peak. More resistant beds of limestone and limestone boulder conglomerate crop out in the lower part of the Adams near Hillard Peak, in the middle part of the formation at the east end of Limestone Hogback, and in the upper part of the formation along the Yukon and Tatonduk Rivers. Some of the limestone is quite sandy, and it grades laterally and vertically into quartzite partly cemented by calcite. Oolitic limestone occurs in the lower part of the formation about a mile northeast of Hillard Peak. All the limestone seems to be lenticular. 


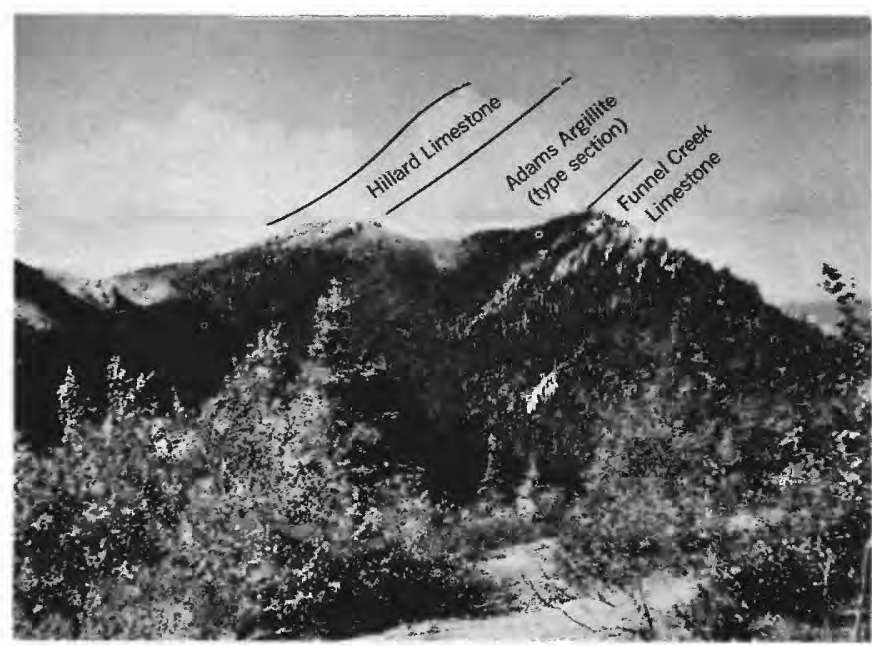

Figure 5.-Cambrian sequence at east end of Limestone Hogback. Apparent angular discordance between the Funnel Creek Limestone and the Hillard Limestone may be caused by faulting or flexuring within the intervening Adams Argillite. View is west from ridge extending north from Hillard Peak.

An isolated outcrop of greenstone occurs about 50 feet above the base of the Adams Argillite about 11/2 miles northeast of Hillard Peak. The greenstone has abundance white calcite amygdules and a somewhat fragmental texture. In thin section, abundant amphibole phenocrysts can be seen in a felted mass of plagioclase crystals. All the minerals are extensively or wholly replaced by calcite, chlorite, and other minerals. The texture and mineralogy of the rock suggest that it may be an altered hornblende andesite.

Greenstone also occurs in the Adams Argillite about 3 miles northeast of the mouth of the Nation River (fig. 1). The stratigraphic position of this greenstone is uncertain, inasmuch as the rocks are extensively folded and faulted.

The Adams Argillite is about 600 feet thick in the Hillard Peak area. It seems to be about 300 feet thick at the east end of Limestone Hogback, but part of the formation may be faulted and missing there. Along the Tatonduk River, it seems to be about 400 feet thick.

Fossils in the Adams Argillite include archaeocyathids, trilobites, worm(?) burrows, and Oldhamia, a trace fossil. The archaeocyathids occur in a boulder conglomerate near the base of the formation in the vicinity of Hillard Peak (see fig. 2, column 1, and p. A23 for locality data), in limestone in the middle part of the formation near Limestone Hogback ( $J$. B. Mertie, Jr., unpub. data), and in limestone in the upper part of the formation along the Tatonduk River. The last locality is probably the same as 30AW62 (see Mertie, 1933, p. 398), from which the following fossils were collected by Aaron Waters and identified by
Edwin Kirk: Archaeocyathus sp., Ethmophyllum sp., and Dorypyge? sp. Kirk assigned these fossils a Middle Cambrian age apparently in the belief that they are associated with Middle Cambrian trilobites at a nearby locality. According to Okulitch and Greggs (1958, p. 622), Ethmophyllum characterizes the middle zone of the Lower Cambrian of the northern Cordilleran region of North America.

Archaeocyathids associated with trilobites were found in limestone thought to be in the upper part of Adams Argillite along the Yukon River (collns. 60ABa222, $60 \mathrm{ABa} 222 \mathrm{~F}, 60 \mathrm{ABa} 222 \mathrm{G}$ and $60 \mathrm{ABa} 222 \mathrm{GA}$ ). The fossils are of Early Cambrian age, according to A. R. Palmer.

Tubes about $2 \mathrm{~mm}$ in diameter and $5-10 \mathrm{~mm}$ in length are common along bedding planes in quartzite within the Adams Argillite. Presumably they are some type of worm burrow. Sandstone in the tubes is finer grained and has more calcite and clay than the surrounding quartzite. Most of the tubes are ovoid in cross section and straight.

Oldhamia, a fan-shaped trace fossil of probable Cambrian age, was found in the Adams Argillite between Hard Luck Creek and the Kandik River (fig. 1). A similar Oldhamia in argillaceous rocks was found by Mertie (1937) in the Mount Schwatka area, and by geologists of the BP Exploration Co. (Alaska), Inc., in the Crazy Mountains of east-central Alaska. A description of these fossils and their stratigraphic significance are given in a report by Churkin and Brabb (1965b).

In summary, the presence of archaeocyathids, trilobites, and Oldhamia, in the formation and a stratigraphic position below a formation containing Early Cambrian fossils indicate that the Adams Argillite is of Early Cambrian age.

The Adams Argillite rests accordantly on the Funnel Creek Limestone. No reworked limestone suggestive of an unconformity was found in the basal quartzite of the Adams Argillite near Hillard Peak and Limestone Hogback, but because of the hasty examination it could have been overlooked. The chert and limestone breccia at the top of the Funnel Creek Limestone along the Tatonduk River could consist of reworked material and be more properly included as the basal deposit of the Adams Argillite, but it seems to be conformable with and a part of the Funnel Creek Limestone.

\section{CAMBRIAN, AND ORDOVICIAN ROCKS} HILLARD LIMESTONE

A resistant fossiliferous limestone that forms crags and escarpments in the Eagle region is a key formation in mapping the structure of the area. It is here named the Hillard Limestone for exposures in the vicinity of 
Hillard Peak, a newly named mountain between McCann Hill and the Yukon River (fig. 3). Hillard Peak is triangulation station "Chief" on Mertie's (1933, pl. 7) map and is BM 4085 on the Eagle D-1 quadrangle map $(1: 63,360), 1956$ edition. The Hillard Limestone extends westward from Hills.rd Peak to the Adams Peak area, and it extends northward from Adams Peak in a continuous band to the Tatonduk River and Montauk Bluff areas. It has also been mapped by Brabb and Churkin (1964) in structurally isolated localities near Hard Luck Creek, near the lower part of the Nation River, and along the U.S.-Canada boundary between Tindir Creek and the Nation River. The Hillard Limestone has also been traced on aerial photographs from its type locality to an area in Canada about 5 miles southeast of Hillard Peak, beyond which area photographic coverage was unavailable.

The type section for the Hillard Limestone is on cliffs about 1.6 miles east of Hillard Peak in the NE1/4 sec. 3, T. 1 N., R. 33 E. The top and a 500-foot-thick section of the formation are exposed there, but the base is concealed. A supplementary section (fig. 6) on a cliff about 1.3 miles north-northeast of Hillard Peak has the top of the Hillard Limestone and a 250-footthick section exposed. Another section, about one-half mile east-northeast of Hillard Peak, contains abundant fossils in the uppermost 75 feet of the formation. The three sections are combined in figure 2, column 1 .

The characteristic lithology of the Hillard Limestone in its type area is fine-grained pale-yellowish-brown $(10 Y R 6 / 2)$ limestone in beds from a fraction of an inch to several feet thick. The lenticular character of some of the beds is shown by figure 6 . Limestone edgewise conglomerate is common, and oolitic limestone was found at one locality. Some of the limestone has been replaced by chert and chalcedony, and in some places it has a few interbeds and nodules of laminated palebrown $(5 Y R 5 / 2)$ and grayish-black (N2) chert.

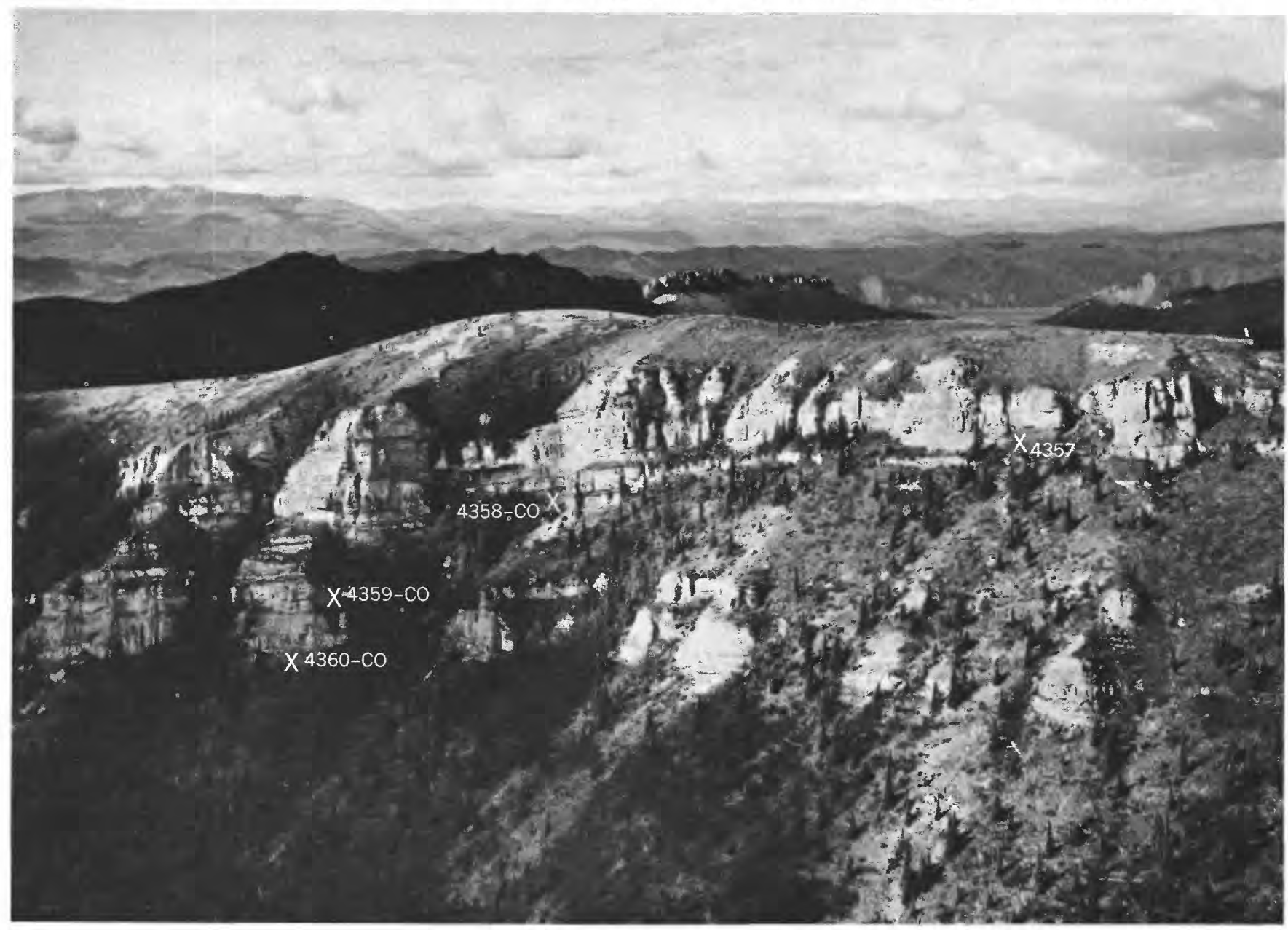

FIGURE 6.-Upper part of the Hillard Limestone on cliffs 1.3 miles north-northeast of Hillard Peak. Numbers indicate fassil collection localities. Note the lenticular character of the bedding. Rounded hills along top of ridge have outcrops of Ordovician graptolitic shale and chert of the Road River Formation (Ordovician and Silurian). Limestone Hogback in middle background is formed of the Funnel Creek Limestone. View is west toward Yukon River. 


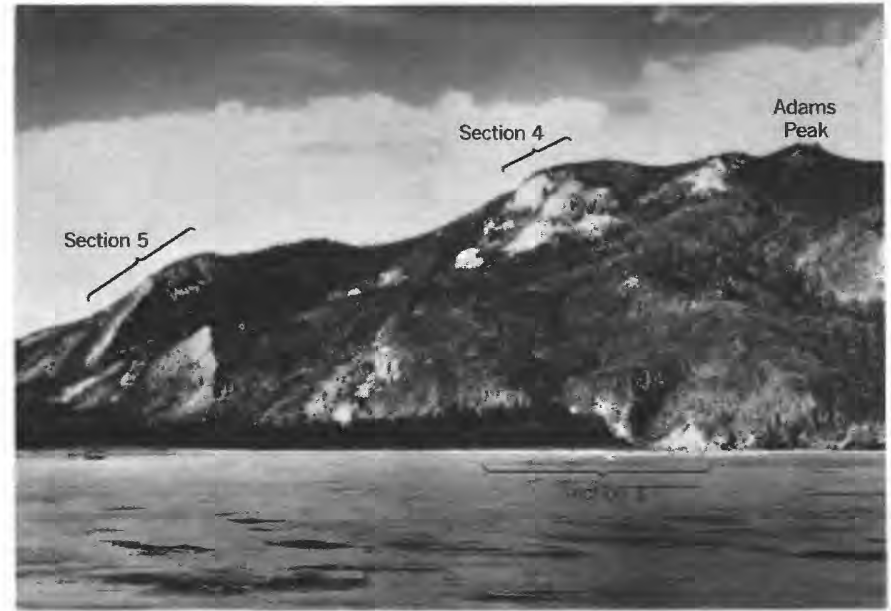

Figure 7.--View north across Yukon River towards Adams Peak showing location of measured sections shown on figure 2, columns 3-5. Low wooded island in foreground obscures the upper part of section 3 .
The Adams Peak-Yukon River area (fig. 7) has fairly well exposed fossiliferous, easily accessible outcrops of Hillard Limestone, but structural complications make this area less suitable than the Hillard Peak area for a type section. Three partial sections were measured, one along the Yukon River (fig. 7, section 3), another near Adams Peak (fig. 7, section 4), and the third on a ridge southwest of Adams Peak (fig. 7, section 5). The section near Adams Peak (fig. 8) is complicated by what seems to be a large slump block on the southwest side of the mountain. The section across a north-trending ridge (fig. 9) and east-trending flatiron about a mile southwest of Adams Peak is complicated by faults(?) and by lateral changes in resistance to erosion of the Hillard Limestone. The top bed of the formation does not strike along the crest of the ridge and flatiron, as one might expect from a study of aerial photographs or from a distant viow of the area. Instead, the upper

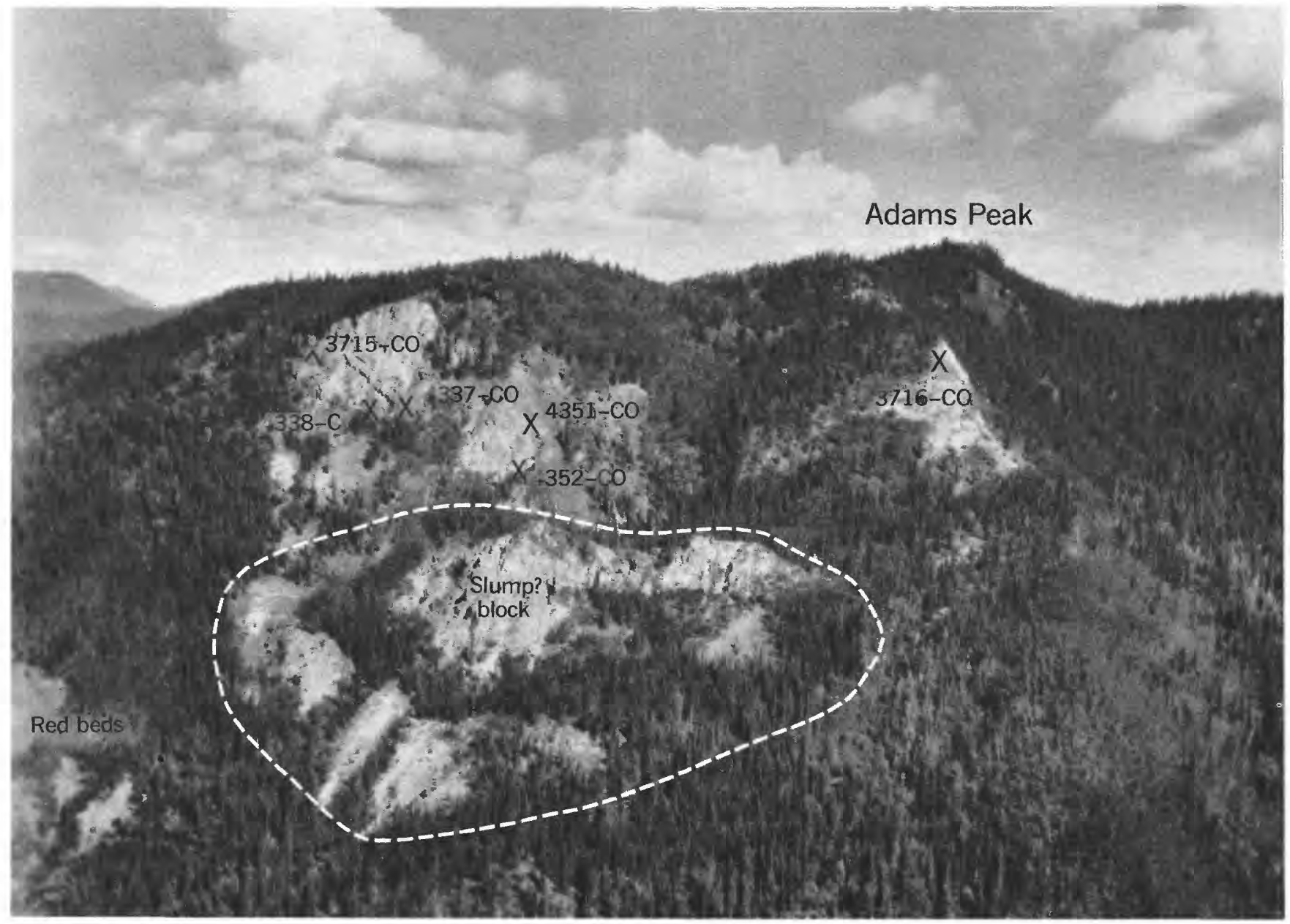

Figure 8.-Cambrian rocks just west of Adams Peak. Fossil collections, indicated by numbers on the photograph, are from the Hillard Limestone. Red beds of Adams Argillite are exposed in the lower left foreground. Talus in the vicinity of collection 4351-CO and 4352-CO is mainly chert and shale from the Road River Formation overlying the Hillard Limestone. The block of limestone in the lower center of the photograph is apparently a slump block. View is north. 


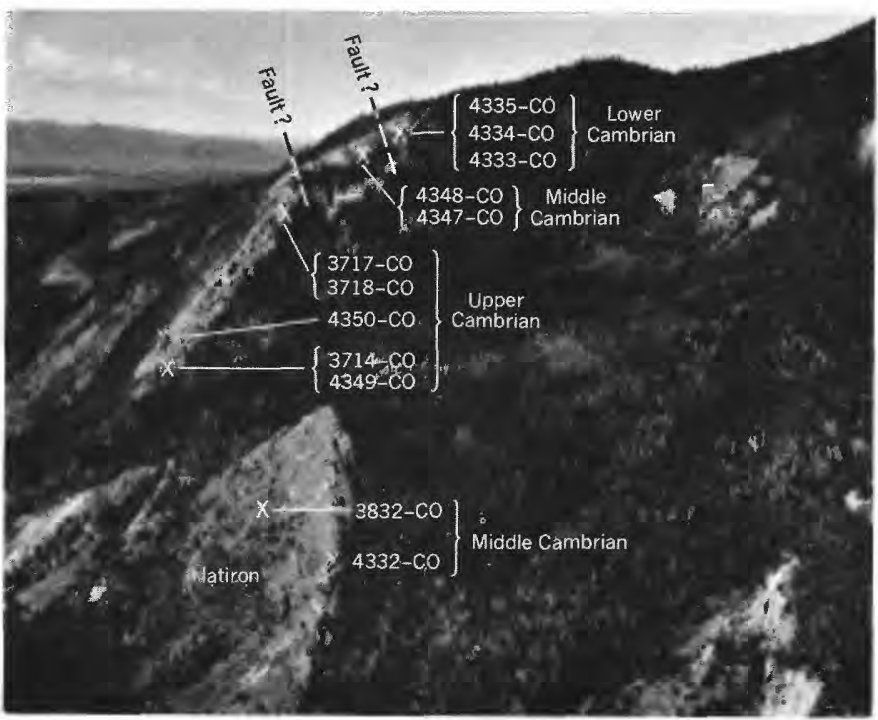

Figure 9.-Exposures of the Hillard Limestone on ridge and flatiron about a mile southwest of Adams Peak. Numbers show fossil localities. Red beds of Adams Argillite in the upper right-hand corner of the photograph are the same ones shown on figure 8. View is northwest.

part of the formation (locs. 4350-CO, 4349-CO, 3714$\mathrm{CO}, 3717-\mathrm{CO}$, and $3718-\mathrm{CO}$, fig. 9) forms only the southern part of the ridge crest. The middle part of the formation forms the middle part of the ridge crest (locs. 4347-CO and 4348-CO) and the prominent flatiron (locs. 3832-CO and 4332-CO). The lower part of the Hillard Limestone is exposed only along the northern part of the ridge crest (locs. 4333-CO, 4334$\mathrm{CO}$ and 4335-CO). The section along the Yukon River is complicated by a fault between outcrops of Hillard Limestone and a limestone apparently within the Adams Argillite.

The lowest beds of the Hillard Limestone exposed in the Adams Peak-Yukon River area are limestone-boulder conglomerate. Some of the boulders are 3 feet in maximum dimension. The boulders consist of pale-yellowish-brown (10YR 6/2) oolitic limestone and finegrained limestone in a matrix of sand-size detrital limestone grains. Phosphate, in the form of chips, pellets, and finely disseminated material in the matrix, is common in the conglomerate. The chips are grayish black and are easily mistaken for the chert fragments that also occur in the limestone. The pellets are the same color as the limestone, pale yellowish brown $(10 Y R 6 / 2)$, and are easily overlooked. Most of the phosphate in the matrix is collophane that may be derived in part from brachiopod-shell material and in part from the associated pellets and chips of phosphatic material.

Within the conglomerate are beds of oolitic limestone and fine-grained limestone similar in lithology to the clasts in the conglomerate; this similarity suggests that the clasts are derived from nearly contemporaneous material.

The boulder conglomerate seems to grade upward into oolitic limestone, fine-grained and thin-bedded limestone, and limestone edgewise conglomerate. These beds in turn are overlain along the Yukon River by dark (N3) and grayish-black (N2) organic shale, siltstone, and laminated limestone. Nearly all of these dark beds are concealed or missing along the ridge southwest of Adams Peak, but the uppermost beds crop out at the base of the cliff in the middle part of the ridge. The dark beds do not occur in the section near Adams Peak.

The rest (upper part) of the Hillard Limestone in the Adams Peak-Yukon River area is predominantly edgewise conglomerate. This conglomerate (fig. 10)

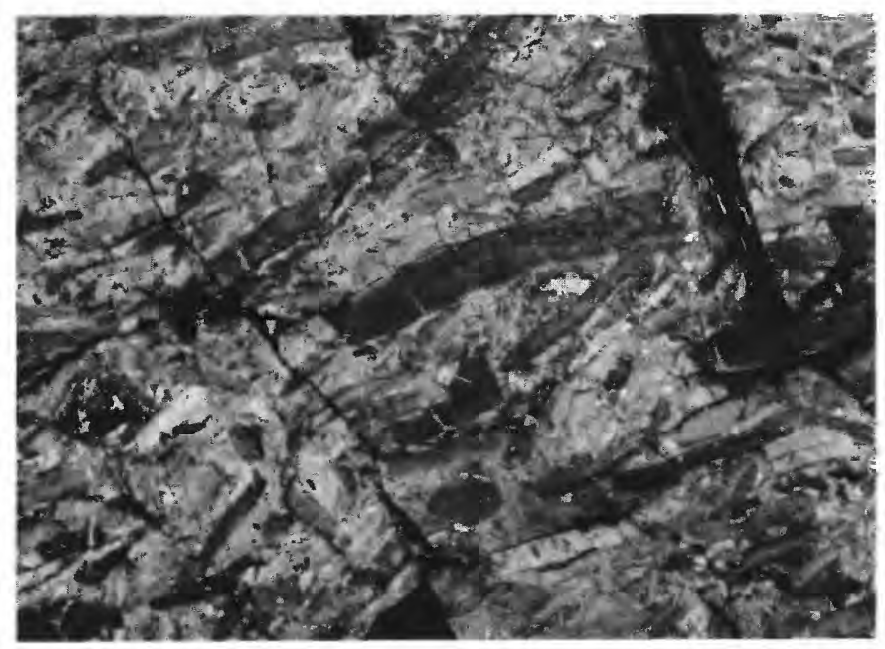

Figure 10.-Limestone edgewise conglomerate characteristic of upper part of the Hillard Limestone along the Yukon River.

consists of small flat pieces of pale-yellowish-brown $(10 Y R$ 6/2) fine-grained limestone, moderately to steeply inclined to the bedding. Most of the limestone pieces are less than 6 inches long, and a few are from 6 to 12 inches long. The pieces are in a matrix of slightly coarser grained limestone that weathers very pale orange $(10 Y R 8 / 2)$ in contrast to the medium-lightgray $(N 6)$ color of the weathered clasts.

Phosphate similar to that in the basal(?) boulder conglomerate was discovered in most of the formic acid residues of samples from the upper part of the Hillard Limestone in the Adams Peak-Yukon River area. The sample richest in phosphate is from the basal part of the limestone edgewise conglomerate in the central part of the ridge southwest of Adams Peak, near collection 3717-CO (fig. 9). X-ray analysis by B. M. Madsen of the U.S. Geological Survey indicates that nearly all the 
phosphate from that sample is apatite having about 2 percent $\mathrm{CO}_{2}$. Crandallite may also be present in trace amounts.

The Hillard Limestone exposed along the Tatonduk River is more thinly bedded, has many more interbeds of shale and siltstone, and has much less edgewise conglomerate than the Hillard in the Adams Peak-Yukon River area. Near the base of the formation two boulder conglomerate beds are separated by shale; each bed projects into the Tatonduk River and forms ledges that are hazards to boats. The basal boulder conglomerate is shown in figure 11. Most of the limestone strati-

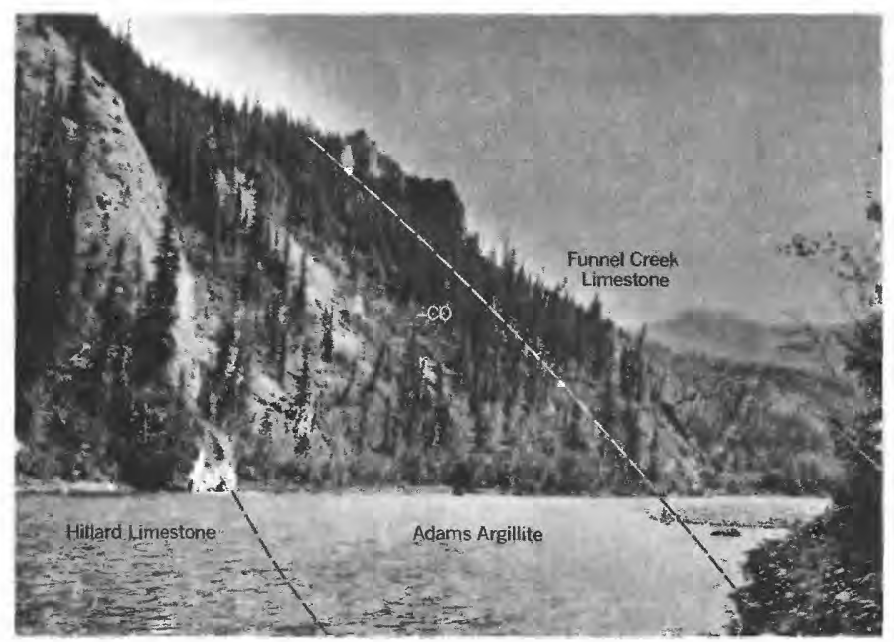

FIGURE 11.-View northeast up the Tatonduk River showing ledge of boulder conglomerate at the base of the Hillard Limestone (left foreground) and exposures of the Adams Argillite and Funnel Creek Limestone on the north valley slope. The beds dip toward the lower left-hand corner of the photograph.

graphically above the conglomerate contains some chert and quartz sand and grit grains, and a few sandy limestone beds grade into limy sandstone. Thin sections indicate that most of the carbonate in the sandy limestone is clastic and that the rock is calcarenite. A few thin graded limestone beds consists mostly of echinoderm fragments.

Pyrite is common in nearly all of the rocks. Most of it is finely disseminated but some occurs in veinlike structures. In one thin section of a limestone, pyrite occurs around the rim of what appear to be recrystallized oolites.

Some of the Hillard Limestone along the Tatonduk River is dolomitic and weathers grayish orange (10YR $7 / 4$ ). On the other hand, some of the limestone contains so much organic material that it is grayish black (N2). A bituminous substance that dissolves in carbon disulfide and colors it black occurs in fractures in this limestone. Most of the limestone contains phosphatic material; one 2-inch bed consisting mainly of brownish- black (5YR 2/1) phosphate chips as much as $30 \mathrm{~mm}$ long occurs in the middle of the limestone section. Three beds of grayish-black (N2) chert from 1 to 12 inches thick occur near the top of the formation.

Sedimentary structures are common in the upper 275 feet of the Hillard Limestone along the Tatonduk River where crossbeds, graded beds, flute casts, and cone-incone structures were observed.

The Hillard Limestone in the area about 4 miles northeast of Montauk Bluff was not carefully examined, but it appears here to be mainly massive limestone. Limestone boulder conglomerate occurs in float near the base of the section. The uppermost part of the formation is thinly bedded, very fine grained, paleyellowish-brown $(10 Y R$ 6/2) limestone.

Along Hard Luck Creek, the Hillard is most similar in gross appearance to its exposures along the Tatonduk River, except that it has more shale. It consists mainly of alternate sets of limestone and shale. Most of the sets are 6 inches to 1 foot thick, and each set contains numerous laminae and (or) graded beds. The limestone sets are more resistant to erosion than the shale interbeds and protrude on weathered surfaces.

In summary, the Hillard Limestone is predominantly fine-grained pale-yellowish-brown limestone in beds a fraction of an inch to several feet thick. Limestone edgewise conglomerate is common in the formation, and shale and limestone boulder conglomerate occur locally.

Near Adams Peak (fig. 2, column 4), Hillard Peak (fig. 2, column 1) and Limestone Hogback (fig. 2, column 2), well-bedded Hillard Limestone is directly overlain by well-bedded chert of the Road River Formation of Ordovician and Silurian age. Along the Tatonduk River (fig. 2, column 6), the ridge 1 mile southwest of Adams Peak (fig. 2, column 5), and Hard Luck Creek (fig. 2, column 8), however, the basal or lower beds of the Road River Formation are a breccia consisting of angular and rounded pebble- to bouldersize clasts of limestone, shale, dolomite, and black chert, all cemented by calcite. The breccia is overlain by graptolite-bearing chert and shale more characteristic of the Road River. In all localities, the change from the Hillard Limestone to chert, shale, and breccia of the Road River Formation is abrupt.

Faults and incomplete exposures make it difficult to determine the exact thickness of Hillard Limestone, but the formation seems to reach a maximum thickness of about 500 feet in the Hillard Peak area. The Hillard Limestone is about 400 feet thick along the Tatonduk River, about 200 feet thick in the vicinity of Adams Peak and Montauk Bluff, and about 100 feet thick along Hard Luck Creek. 
Fossils are fairly common in the Hillard Limestone (see fig. 2 for position of fossil collections in the sections measured). Fossils collected from beds a few inches apart and put in the same collection, however, may become a mixed fauna representing different stages, series, or systems. Such difficulties evidently led Kirk (see Mertie, 1933, p. 398) to conclude erronously that archaeocyathids in the Adams Peak area must be Middle Cambrian because they are associated with Middle Cambrian trilobites. Still another difficulty in collecting fossils and determining their stratigraphic position in this formation is that incomplete exposures make it difficult to locate the top and bottom of the formation. The problem in locating the top of the Hillard Limestone along the ridge and flatiron southwest of Adams Peak has already been mentioned. It is also difficult to locate the base of the formation in the Hillard Peak area because the break in slope from cliff exposures to rounded hills does not exactly mark the contact between the Hillard Limestone and underlying Adams Argillite, as one would expect. Some of the rounded hills are vegetation-covered talus piles that conceal different parts of the Hillard Limestone at different localities.

In spite of these difficulties, the faunal succession within the Hillard Limestone is thought to be reasonably well established. A. R. Palmer (written commun., 1965) furnished the information for the following brief discussion.

The oldest fossil, an archaeocyathid of Early Cambrian age, was observed by Palmer in what appeared to be the matrix of boulder conglomerate in the lower (basal?) part of the Hillard Limestone along the Yukon River. The specimen could not be collected. Archaeocyathids were also observed by Palmer in boulders within limestone boulder conglomerate float near the base (?) of the Hillard Limestone northeast of Montauk Bluff and were collected (4338-CO) from boulders in the lower (basal?) part of the formation near Adams Peak. The archaeocyathids in these boulders are obviously reworked, but whether the reworked boulders are virtually contemporaneous or considerably older could not be determined. Trilobites of Early Cambrian age (colln. 4302-CO) were obtained from a boulder in the basal bed of the Hillard Limestone along the Tatonduk River.

Three collections of trilobites and other fossils of slightly younger Early Cambrian age were obtained from the uppermost part of the boulder conglomerate along the ridge southwest of Adams Peak. Two collections (4333-CO and 4334-CO) are from limestone interbedded with the boulder conglomerate, and 4335-CO is from one of the limestone boulders. Inasmuch as the faunas are all the same age, according to Palmer, the boulders at that locality were apparently derived from the reworking of nearly contemporaneous material.

Fossils of early Middle Cambrian age, according to Palmer, were collected (4341-CO) from bedded limestone about 40 feet above the base of the exposed section of the Hillard Limestone in the vicinity of Hillard Peak (fig. 2, column 1). Similar faunas were obtained from 10 to 20 feet above the basal(?) boulder conglomerate in the Yukon River-Adams Peak area (4330-CO, 4348$\mathrm{CO}$ ), from the lowest exposures of the formation northeast of Montauk Bluff (4346-CO), and from limestone interbedded with boulder conglomerate in the lower part of the formation along the Tatonduk River (4303$\mathrm{CO}, 4339-\mathrm{CO}$, and 4340-CO). Fossils of younger Middle Cambrian age were collected from 400 (4345-CO) to 430 (4344-CO) feet below the top of the Hillard Limestone in the Hillard Peak area, and about 100 feet below the top of the formation, near Adams Peak (4337-CO), along the ridge and flatiron southwest of Adams Peak (4347-CO and 3832-CO), and along the Tatonduk River (4310-CO).

Fossils of early Late Cambrian (Dresbachian) age, according to Palmer, were collected about 250 feet below the top of the Hillard Limestone in the Hillard Peak area $(4360-\mathrm{CO})$ and from 70 to 100 feet below the top of the formation along the ridge southwest of Adams Peak (3717-CO and 3718-CO), along the Tatonduk River (4326-CO), and along Hard Luck Creek (4376CO). Fossils of middle Late Cambrian (Franconian) age were collected from 1 to 200 feet below the top of the Hillard near Hillard Peak (4359-CO, 4358-CO, 4357-CO, 4356-CO, 4355-CO, and 3709-CO), about 30 feet below the top of the formation near Limestone Hogback (3710-CO), and about 10 feet below the apparent top of the formation near Montauk Bluff 4379-CO).

Fossils of late Late Cambrian (Trempeleauan) age, according to Palmer, were collected from 1 to 30 feet below the top of the Hillard Limestone near Adams Peak (4351-CO, 4352-CO). Collections 4349-CO and 3714-CO from the ridge southwest of Adams Peak may be the same age. A fauna of early Early Ordovician age was collected (4353-CO) from the uppermost beds of the Hillard Limestone about 800 feet above the Tatonduk River on its north valley slope (fig. 4). This collection is not shown on figure 2 because the beds appear to be faulted out at river level where the section was measured.

In summary, fossils indicate that the Hillard Limestone ranges in age from Early Cambrian to Early Ordovician. At all but one locality the formation is not younger than Late Cambrian. 
The Road River Formation, which unconformably overlies the Hillard Limestone, ranges in age from middle or late Early Ordovician (Arenigian or Llanvirnian) to Late Silurian (Ludlovian), according to Churkin and Brabb (1965a, fig. 3). The Road River Formation evidently rests on beds of the Hillard Limestone possibly as old as early Late Cambrian (Dresbachian) along Hard Luck Creek, and middle Late Cambrian (Franconian) near Hillard Peak, Limestone Hogback, and Montauk Bluff. The indicated stratigraphic hiatus is as much as four or five stages (part of the Dresbachian, all the Franconian, Trempeleauan, and Tremadocian, and most or all of the Arenigian) along Hard Luck Creek, and as little as one or two stages (parts of the Tremadocian and Arenigian or Llanvirnian) along the Tatonduk River.

\section{JONES RIDGE LIMESTONE}

A previously unnamed limestone formation is exposed in magnificient and spectacular cliffs and jagged peaks in the horseshoe-shaped series of ridges and peaks from Jones Ridge to triangulation station Hi-yu (BM 4839) and to Squaw Mountain. This formation was mapped as an undifferentiated limestone of Cambrian to Devonian age by Cairnes (1914b), and it furnished most of his Upper Cambrian fossil collections (see p. A29). Mertie (1933) supplemented the collections of Cairnes and found new faunas of Early and Middle Ordovician and "Middle" (now considered Early) Cambrian age in this limestone. On his geologic map, Mertie differentiated this limestone from all the other formations of Cambrian and Ordovician age in the Eagle region. The formation is here named the Jones Ridge Limestone for exposures in the vicinity of Jones Ridge.

The Jones Ridge Limestone seems to be limited in areal extent to the Jones Ridge-Hi-yu-Squaw Mountain area and to a small adjoining area in Canada.

The type section of the Jones Ridge Limestone (fig. 2, column 9 ) is designated as the central part of sec. $3, \mathrm{~T}$. 3 N., R. 33 E., where the base of the formation is exposed, then across the crest of Jones Ridge to the northwestern part of section 10 , at an altitude of about 3,300 feet. The top of the formation is at the base of a 60 foot largely covered interval, which presumably contains shale, chert, and limestone. The type section of the Jones Ridge Limestone is completely exposed, accessible, and quite fossiliferous, at least in its upper part. The section from collection 4361-CO to 4365-CO was measured by tape, and I estimated the thickness of the section from 4361-CO to the base of the formation.

The Jones Ridge Limestone is provisionally and informally subdivided into two members. The lower member is predominantly fine-grained limestone, whereas the upper member is predominantly medium- to coarse-grained bioclastic limestone. The lateral continuity of these members is not as yet well established.

\section{LOWFR MEMBER}

The lower 2,000 feet of the lower member consists primarily of very light gray $(N 8)$ massive limestone and dolomite. Some of the limestone is oolitic and pisolitic. The irregular distribution of the dolomite suggests that it is secondary and that the rock was originally entire limestone. The rock is extensively silicified, particularly in the basal 500 feet of the member.

The limestone and dolomite grade upward into approximately 940 feet of light-olive-gray $(5 Y 6 / 1)$ and pale-yellowish-brown $(10 Y R 6 / 2)$ very fine grained, thin- to thick-bedded limestone. Some of the limestone is silicified and some is oolitic. No other lithologic variations were noted along the measured section, but a thin bed of sandy limestone containing glauconite and (or) chlorite was found near the base of this interval along the upper part of Hard Luck Creek.

The lower member of the Jones Ridge Limestone is about 2,940 feet thick.

No fossils were found in the lower 2,300 feet of the lower member of the Jones Ridge Limestone at its type section, but these rocks were not extensively examined. Archaeocyathids were collected (4301-CO) about 500 feet above the base of the member about 3 miles southwest of Jones Ridge (fig. 12) and about 3,500 feet northwest of triangulation station Hi-yu. Additional specimens of excellently preserved archaeocyathids were collected (4301-CO) about 2,000 feet south of Hi-yu. Waters (in Mentie, 1933, p. 398, colln. 30AW58-59) found archaeocythids about 3,000 feet west of Hi-yu, but the stratigraphic position of these collections is uncertain because the rocks are faulted.

At the type section of the Jones Ridge Limestone, the lowest fossils (4361-CO) from the lower member are of early Late Cambrian (Dresbachian) age, according to A. R. Palmer. Fossils 4374-CO and 4371-CO, of late Late Cambrian (Trempeleauan) age, according to Palmer, were found from 2,630 to 2,740 feet above the base of the member. The highest collections (4367-CO, $4368-\mathrm{CO}$, and 4369-CO) from the lower member are of Early Ordovician age, according to R. J. Ross, Jr.

In summary, the lower member of the Jones Ridge Limestone may range in age from Early Cambrian to Early Ordovician. No fossils of Middle Cambrian and middle Late Cambrian (Franconian) age were found, but the part of the section where the fossils would occur has not been carefully examined. 
The lower member rests accordantly and probably conformably on a 300 -foot-thick formation consisting of grayish-black "platy" limestone, carbonaceous shale, and quartz-rich sandstone and siltstone. This formation is most similar in lithology to Mertie's (1933) unit A of the Tindir Group which he described but did not map in the vicinity of the Tatonduk River. Mertie did not recognize unit A in the Jones Ridge-Squaw Mountain area, but outcrops of the formation there are small and discontinuous and easily overlooked.

Fossils and stratigraphic sequence (fig. 13) indicate that the lower member of the Jones Ridge Limestone is correlative with the Funnel Creek Limestone, Adams Argillite, and Hillard Limestone.

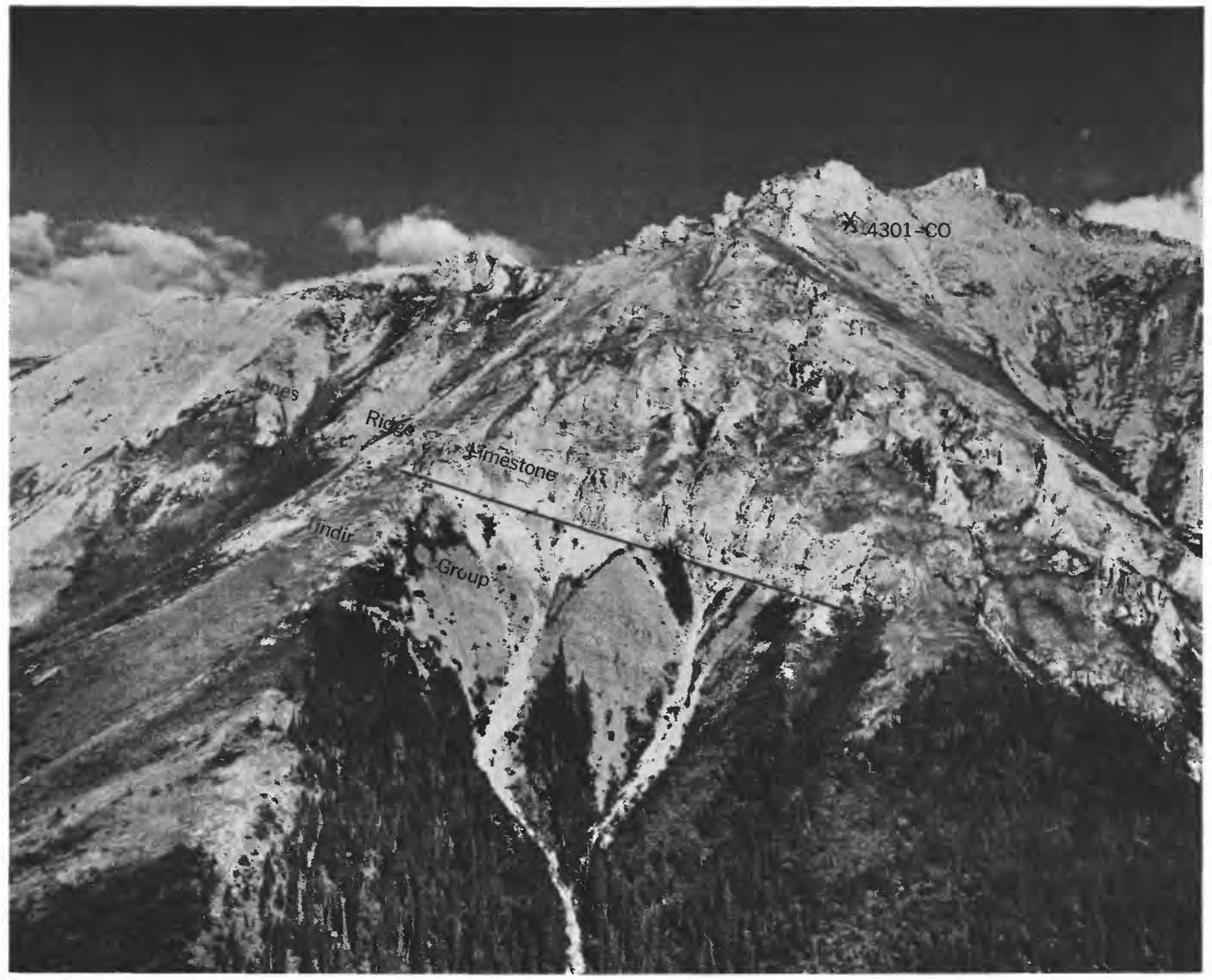

Figure 12.-Contact between unit A of the Tindir Group and the lower member of the Jones Ridge Limestone about 0.8 mile northwest of triangulation station Hi-yu. Archaeocyathids were collected at locality 4301-CO. View is east. 
STRATIGRAPHY, CAMBRIAN AND ORDOVICIAN ROCKS

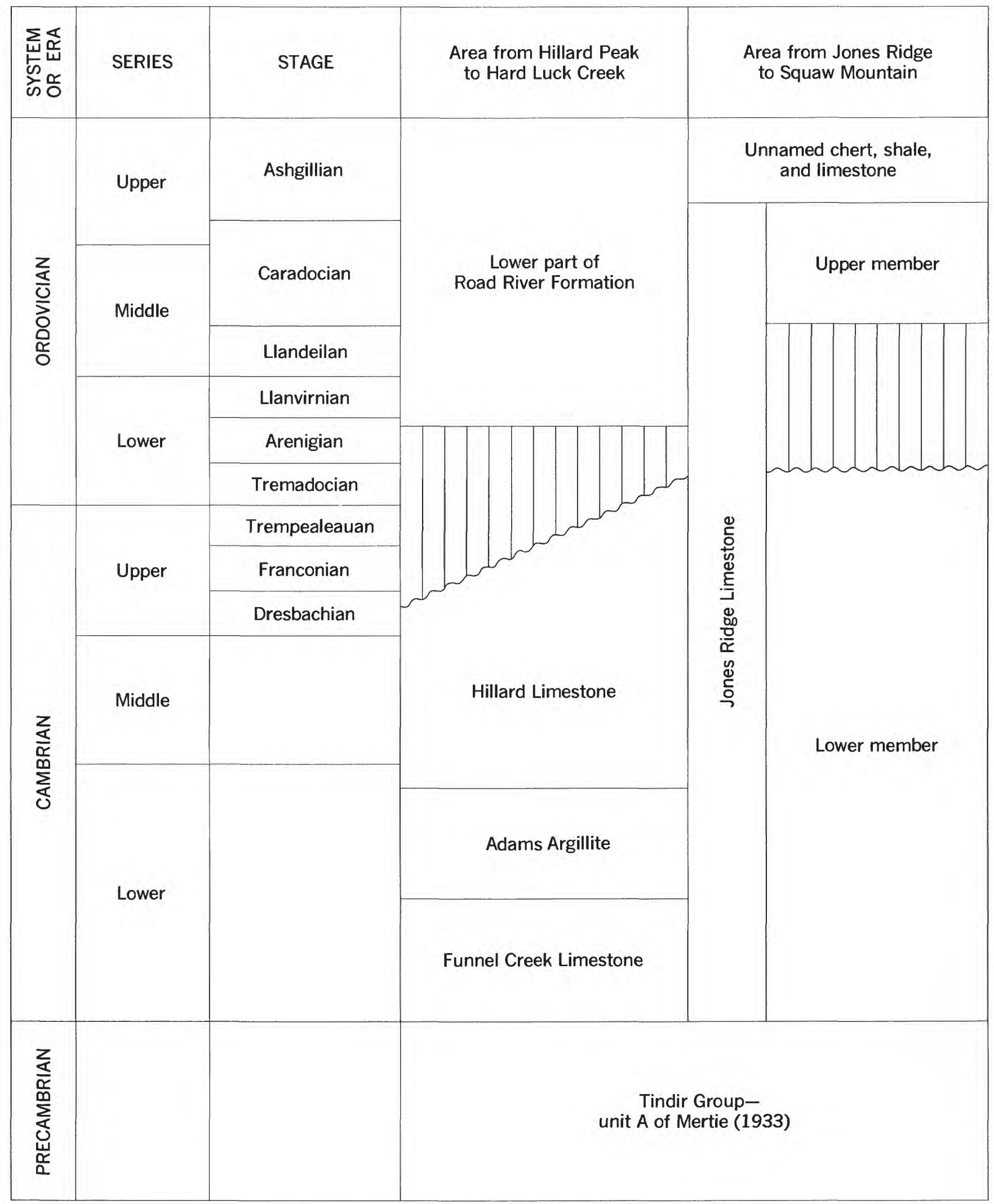

FIGURE 13.-Stratigraphic columns of lower Paleozoic formations of east-central Alaska and their correlation. 


\section{UPPER MUMBER}

The upper member consists chiefly of about 60 feet of pale-yellowish-brown (10YR 6/2) medium- to coarse-grained, thickly bedded bioclastic limestone. A representative view of the upper member and the upper part of the lower member is shown on figure 14. Some

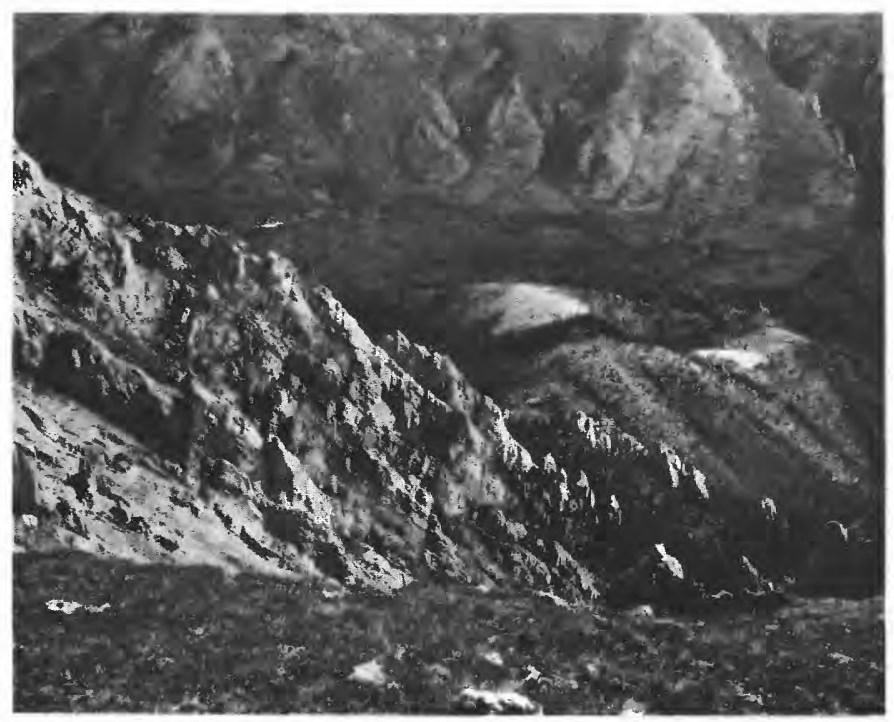

FIGURE 14.- Upper part of Jones Ridge Limestone on south slope of Jones Ridge. Rounded bare slopes in middle background have exposures of McCann Hill Chert of Middle and Late Devonian age. View is south.

very fine grained limestone similar to that characteristic of the lower member is interbedded with the coarser grained limestone. Most of the coarser grained limestone consists of probable pelmatozoan fragments and lesser amounts of trilobite and brachiopod fragments.

The following fossils from the upper member were identified by R. J. Ross, Jr. :

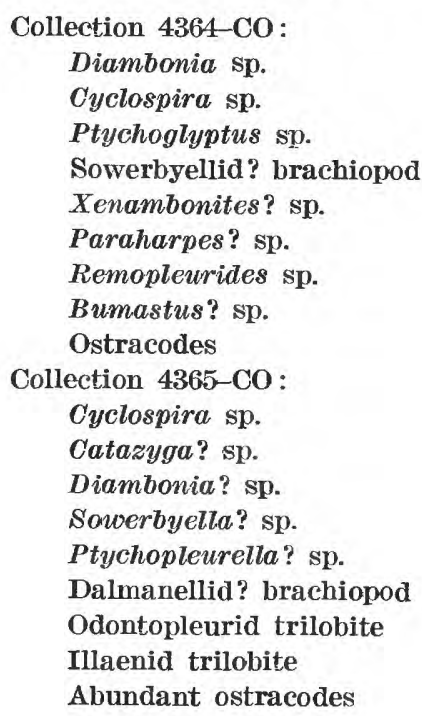

Collection 4366-CO:

Illaenus? sp.

Asaphid pygidium

Streptelasmatoid coral

Ostracodes, undet.

Ross believes that these faunas are probably of late Middle or early Late Ordovician (Caradocian) age and are possibly as young as late Late Ordovician (Ashgillian). W. A. Oliver, Jr., examined the coral from 4366-CO and determined that it is not older than Middle Ordovician. Ostracodes from 4364-CO and 4365-CO were examined by J. M. Berdan, who identified the following species:

Collection 4364-CO: Eurychilina? sp. Acronotella? sp. Steusloffina sp. cf. \$. ulrichi Teichert Smooth ostracodes, undet.

Collection 4365-CO: Aparchites? sp. Hesperidella? sp. Platybolbina? sp. Eohollina sp. Steusloffina sp. cf. S. utrichi Teichert Smooth ostracodes, undet.

These fossils, according to Berdan, are either of Middle or Late Ordovician age.

R. J. Ross, Jr., collected a fauna (D1072-CO) similar to that in collections $4364-\mathrm{CO}, 4365-\mathrm{CO}$, and $4366-\mathrm{CO}$ from limestone and chert about 1 mile west and along the strike from the Jones Ridge section (fig. 3). Presumably it is from the upper member of Jones Ridge Limestone. The following fossils in the collection were identified by Ross and Dutro (1966) :

Collection D1072-CO :

Ptychopleurella ef. P. lapworthi (Davidson)

Dicoelosia jonesridgensis Ross and Dutro

Camerella? sp.

Rhynchotrema? sp.

Cyclospira cf. C. glansfagea Cooper and Kindle Cyclospira? sp.

Catazyga homeospiroides Ross and Dutro Whitfieldella? sp.

Anoptambonites ef. A. grayae (Davidson)

Diambonia cf. D. anatoli Spjeldnaes

Diambonia sp. 1

Diambonia sp. 2

Xenambonites ef. $X$. revelatus Williams

Ptychoglyptus? cf. P.? pauciradiatus Reed

Christiania sp.

Ross believes that this collection, like 4364-CO, 4365-CO, and 4366-CO, is probably of early Late Ordovician (Caradocian) age and possibly as young as late Late Ordovician (Ashgillian). Dutro believes, however, that this collection is late Late Ordovician (Ashgillian). 
In summary, fossils indicate that the upper member of the Jones Ridge Limestone is either of Middle or Late Ordovician age.

The fossil evidence suggests that part of the Lower and part or all of the Middle Ordovician are missing at the contact between the lower and upper members. No other evidence for an unconformity was observed. Inasmuch as the members seem to be accordant, the indicated break is evidently a disconformity.

The tentative correlation of the upper member is shown on figure 13. The upper member is correlative with the lower part of the Road River Formation of Ordovician and Silurian age.

In summary, the Jones Ridge Limestone is of Cambrian to Middle or Late Ordovician age. There seems to be at least one disconformity within the formation.

UNNAMED CHERT, SHALE, AND LIMESTONE

Approximately 30 feet of section stratigraphically above the top of the Jones Ridge Limestone at the type locality is covered. Float in this 30 -foot interval is predominantly grayish-black chert and shale. A 5-footthick bioclastic limestone, similar in lithology to limestone of the upper member of the Jones Ridge Limestone, crops out about 30 feet above the top of the member. About 25 feet of section above this 5-footthick limestone is covered, but chert and shale were found in float in this interval. The base of a 300-footthick limestone, referred to by Churkin and Brabb (1965a) as the basal limestone member of the McCann Hill Chert of Middle and Late Devonian age, crops out 60 feet above the top of the upper member of the Jones Ridge Limestone.

Corals from the 5-foot-thick limestone 30 feet above the top of the upper member of the Jones Ridge Limestone were identified by W. A. Oliver, Jr.:

Collection 4387-COO

Calapoecia sp.

Manipora sp.

Grewingkia sp.

Horn corals, undet.

These corals are of Late Ordovician age, according to Oliver. They indicate that at least part of the 60 -foot largely covered interval between the top of the Jones Ridge Limestone and the basal limestone member of the McCann Hill Chert is correlative with part of the Road River Formation of Ordovician and Silurian age. If the chert and shale found in float in the 60-foot largely covered interval are more representative of the lithology than the 5-foot-thick limestone bed that crops out and if this chert and shale represent a mappable formation, then the Road River Formation can be extended to include these beds in the Jones Ridge-Squaw Mountain area.

\section{PALEOTECTONIC IMPLICATIONS}

The Jones Ridge Limestone is nearly surrounded laterally by contemporaneous rocks of different lithology. A facies map by Douglas and others (1963, fig. 4) indicates that in Canada from 80 to 250 miles east and northeast of Jones Ridge contemporanous rocks are predominantly siltstone, sandstone red beds, salt, and anhydrite. Contemporaneous rocks northwest, west, southwest, and south of Jones Ridge include clastic rocks of the Adams Argillite, shale and chert of the Road River Formation, and limestone containing boulder and edgewise conglomerate. The only nearby area that seems to have carbonate sequences equivalent to the Jones Ridge Limestone is in Canada from 30 to 200 miles east-southeast of Jones Ridge (Green and Roddick, 1962), but the age of the Cambrian and Ordovician rocks in that area is not yet well established, so it is not possible to determine if the rocks are coeval.

Large-scale thrust faulting is one explanation for the "island" of Cambrian and Ordovician limestone in the Jones Ridge-Squaw Mountain area. The rocks are structurally isolated by major faults from those in the Hillard Peak-Hard Luck Creek area (fig. 3), and a tectonic map of northern Canade by Douglas and others (1963, fig. 2) indicates that what appears to be the eastern boundary of rocks in the Jones Ridge-Squaw Mountain area is a thrust fault dipping beneath the "island." The Jones Ridge Limestone and adjoining formations, therefore, may be entirely allochthonous.

A structural explanation for the "island" of carbonate rock does not, however, appear to be warranted. The faults separating the Jones Ridge Limestone from the Hillard Limestone, Adams Argillite, Funnel Creek Limestone, and other formations seem to be high-angle faults rather than low-angle thrusts. A few formations, such as the McCann Hill Chert and unit A of the Tindir Group, occur in both the "allochthonous" and "autochthonous" blocks.

\section{FACIES AND THEIR ECOLOGICAL IMPLICATIONS}

Rapid lateral changes in lithology seem to explain adequately the "island" of carbonate rock in the Jones Ridge-Squaw Mountain area. The facies and their ecological implications are discussed in chronological order, from Early Cambrian to Middle or Late Ordovician.

\section{EARLY CAMBRIAN}

During the desposition of the Funnel Creek Limestone and the lower part of the lower member of the Jones Ridge Limestone in early Early Cambrian time (fig. $15 \mathrm{~A})$, the area from the Tatonduk River to the Nation 


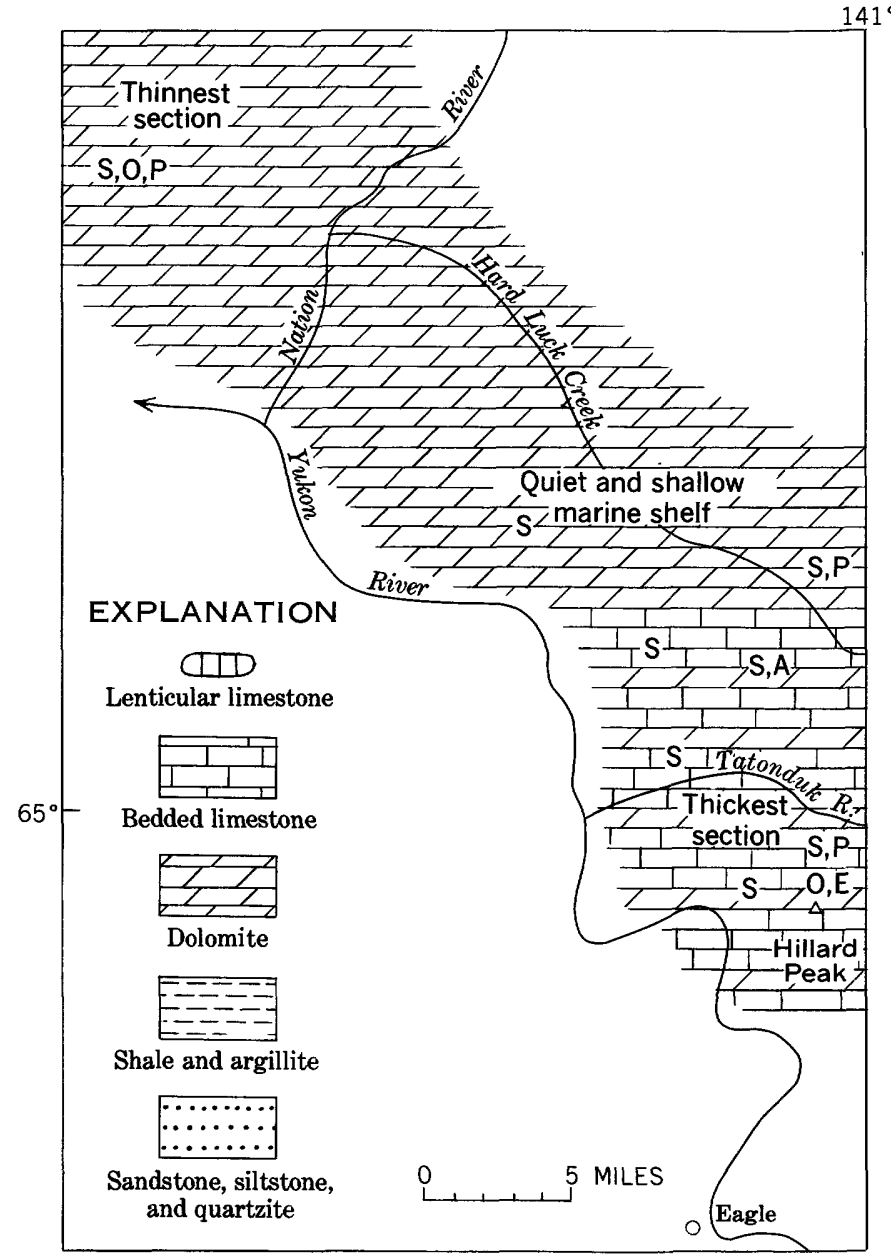

$A$

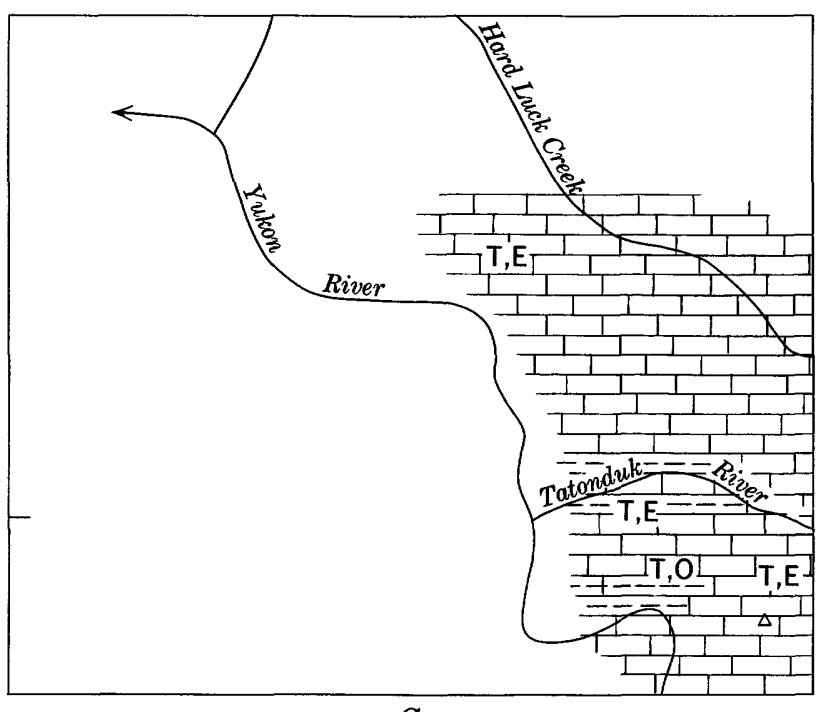

$C$

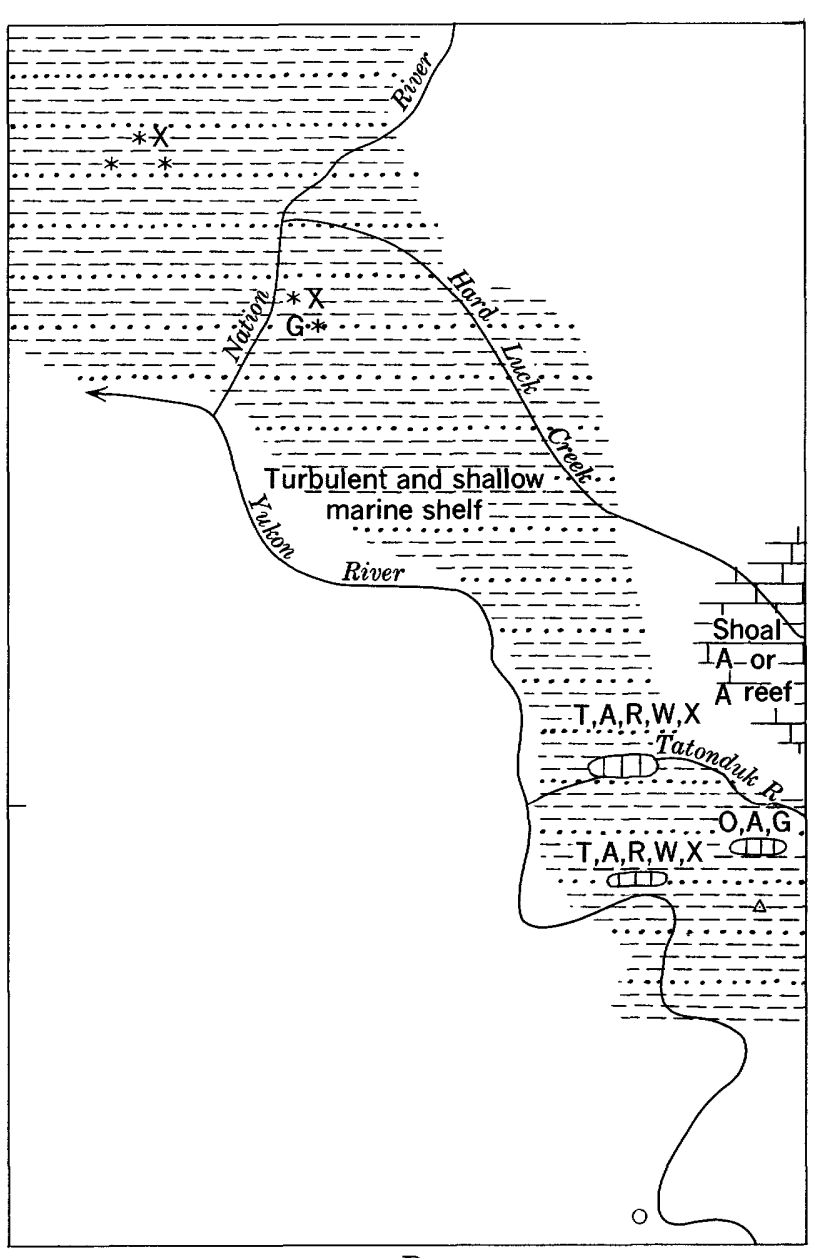

$B$

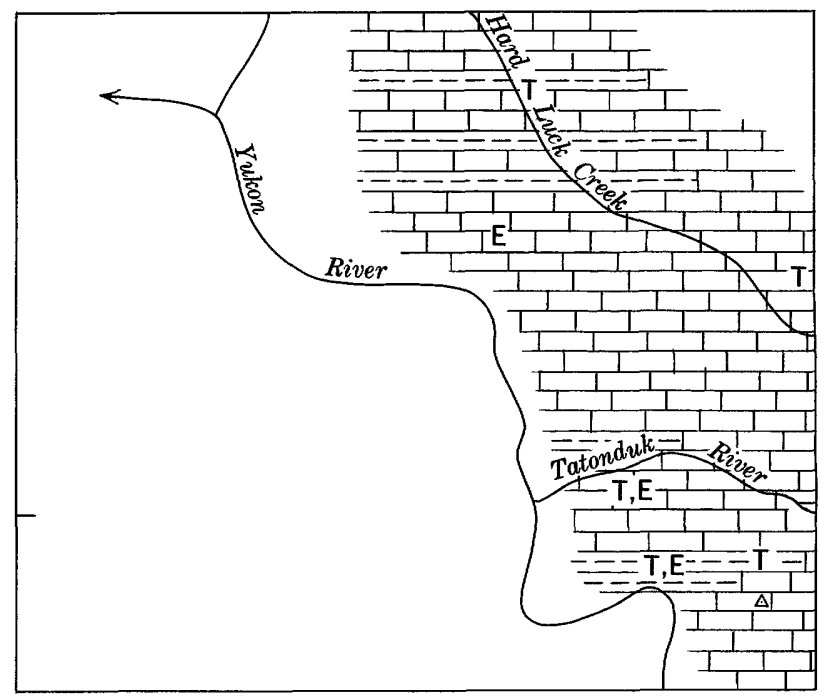

$D$

FigURE 15.-Lithofacies maps of the Hillard Peak-Nation River area from Early to Late Cambrian. A, early Harly Oambrian; $B$, middle and late Early Cambrian; $C$, Middle Cambrian; $D$, early Late Cambrian (Dresbachian). A, archaeocyathids ; E, edgewise conglomerate; G, greenstone ; $O$, oolites ; P, pisolites ; R, red beds ; $\mathbf{S}$, secondary silica; T, trilobites and other fossils; W, worm (?) borings; $\times$, crossbeds ; *, Oldhamia localities. 
River appears to have been a relatively quiet shallow marine shelf, as indioated by the uniform lithology and laminated character of the rocks and by archaeocyathids which, according to Okulitch (1955, p. E2), indicate shallow clear seas. If limestone was the dominant deposit throughout the area, then most of it in the northern part and some in the southern, part was dolomitized. The prevalence of irregularly shaped siliceous veins and vugs in the limestone and dolomite suggests that dolomitization, if it did occur, was accompanied by silicification. Pisolites and oolites and, more locally, edgewise conglomerate in the rocks are suggestive of periods of high-energy deposition, but these conditions were not predominant.

The limestone and dolomite are thickest in the area south of the Tatonduk River and thinnest northwest of the Nation River, but fossil control is not sufficient to show that deposition was more rapid in the former area.

Conditions changed radically in middle and late Early Cambrian time (fig. 15B) during deposition of the Adams Argillite and the middle part of the lower member of the Jones Ridge Limestone, except in the Jones Ridge-Squaw Mountain area where deposition of limestone continued in shallow clear water. Sand, silt, and clay were washed into the rest of the area from unknown sources. Red beds, cross laminations, worm(?) burrows, oolites, trilobites, and other fossils collectively indicate that the water was marine, well oxygenated, shallow, and turbulent.

The paucity of terrigenous material in the lower nember of the Jones Ridge Limestone and the limited and somewhat circular areal extent of this limestone suggest that there may have been a reef in the Jones Ridge-Squaw Mountain area during the Early Cambrian. No skeletal framework suggestive of reef structure was found, however. Perhaps the term limestone shoal is more appropriate.

Some of the sandy, oolitic, and conglomeratic limestone in the Adams Argillite may have been reworked from the limestone shoal in the Jones Ridge-Squaw Mountain area, and some may have been precipitated on local shoals.

The extrusive character of greenstone in the Adams Argillite has not been proved, but volcanism could have occurred during the Early Cambrian. The chlorite and iron in the sediments could have been derived from the greenstone.

\section{MIDDLE CAMBRIAN}

A return to predominantly carbonate deposition occurred during the Middle Cambrian, as reflected by the lithology of the lower part of the Hillard Limestone and the middle part of the lower member of the Jones Ridge Limestone (fig. 15C). Edgewise and boulder conglomerates and oolitic limestone indicate intermittent turbulent conditions in the western and southern part of the area. Limestone and shale were deposited locally in the Tatonduk River area and along the Yukon River south of Adams Peak. The abundant organic material and pyrite in both the shale and associated limestone suggest that reducing conditions prevailed in these area.

\section{LATE CAMBRIAN AND EARLY ORDOVICIAN}

Conditions during the deposition of the middle and upper part of the Hillard Limestone and the lower member of the Jones Ridge Limestone during the early Late Cambrian (fig. 15D), middle Late Cambrian (fig. $16 A$ ), late Late Cambrian (fig. 16B), and early Ordovician (fig. $16 C$ ) were somewhat similar to those during the Middle Cambrian. Limestone was the predominant deposit. Considerable shale was deposited in the Tatonduk River and Hard Luck Creek areas and near the Yukon River south of Adams Peak. Edgewise conglomerate, suggestive of turbulent conditions, was deposited in the western and southern part of the area. The conglomerate could have been derived from the contemporaneous erosion of a shoal or reef in the eastern part of the area, near Jones Ridge.

During the Early Ordovician, deposition of limestone was interrupted and the area was differentially uplifted and eroded. The Hard Luck Creek area was evidently uplifted the most, the Hillard Peak area somewhat less, and the Tatonduk River to Jones Ridge area the least; these uplifts suggest that fold axes during the Early Ordovician were oriented approximately northeastsouthwest.

Deposition resumed in latest Arenigian or earliest Llanvirnian time (Early Ordovician) in the Hillard Peak to Hard Luck Creek area (Churkin and Brabb, 1965a). The basal deposits of the Road River Formation are chert, chert grit, and a chert and limestone breccia, and the succeeding deposits are chert and shale containing graptolites and other fossils. The Jones Ridge-Squaw Mountain area was either being eroded during this time or was not receiving sediments. The occurrence of limestone boulders well above the base of the Road River Formation (Churkin and Brabb, 1965a, fig. 4, column 3) suggests that the area was being eroded. 


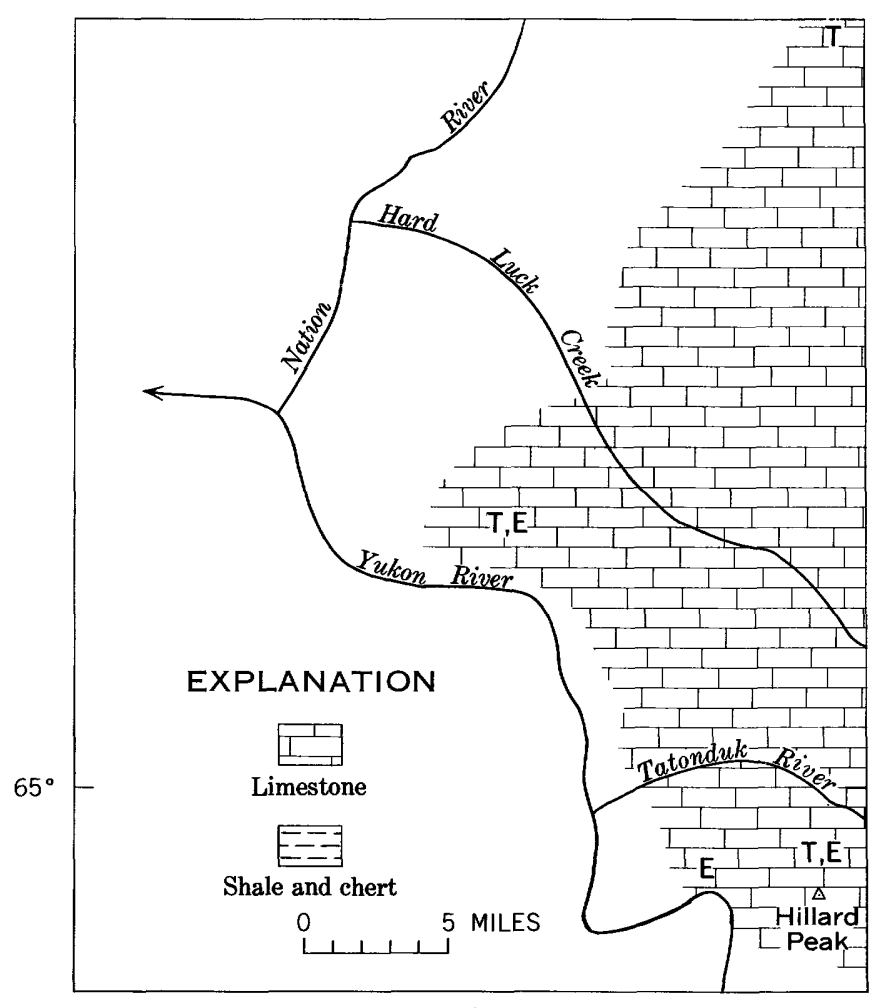

$A$

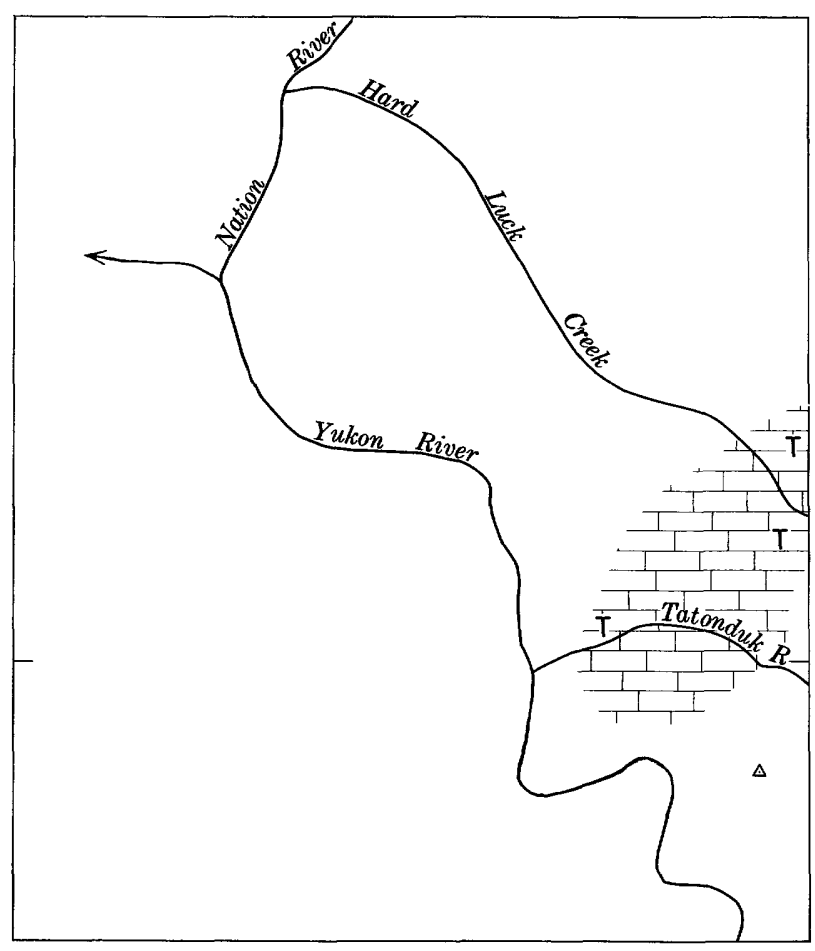

$C$
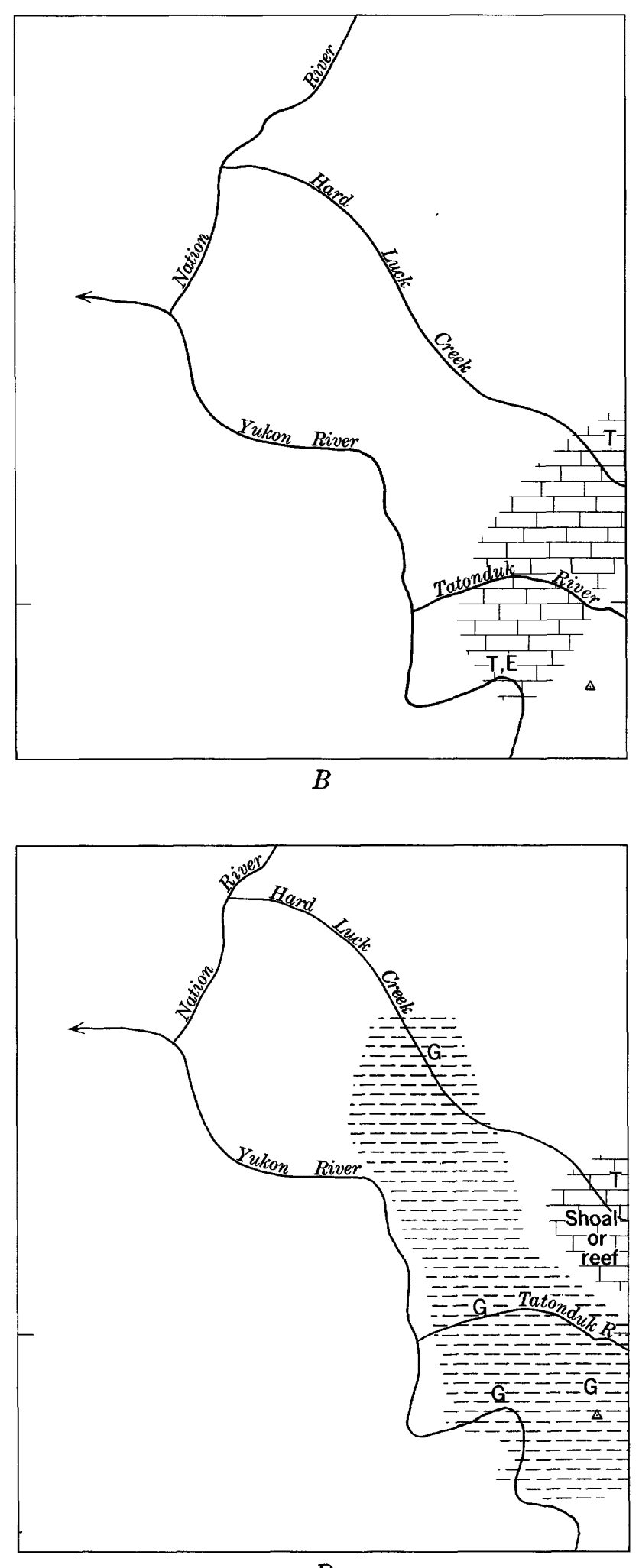

Figure 16.-Lithofacies maps of the Hillard Peak-Nation River area from Late Cambrian to Middle or Late Ordovician time. $A$, middle Late Cambrian (Franconian); $B$, late Late Cambrian (Trempeleauan) ; $C$, Early Ordovician (Tremadocian); $D$, Middle or Late Ordovician (Caradocian or Ashgillian); $E$, edgewise conglomerate; $G$, graptolites and other fossils; $T$, trilobites and other fossils. 


\section{MIDDLE OR LATE ORDOVICIAN}

Deposition did not resume in the Jones Ridge-Squaw Mountain area until Middle or Late Ordovician (Caradocian or Ashgillian) time (fig. 16D) when the bioclastic limestone of the upper member of the Jones Ridge Limestone was deposited. As in the limestone of the Lower Cambrian, no skeletal framework suggestive of reef structure was found, but the limited and somewhat circular extent of this limestone, its prolific fauna, and the paucity of terrestrial material in the limestone suggest that the Jones Ridge-Squaw Mountain area was the site of a shoal or reef during the Middle or Late Ordovician.

\section{SUMMARY}

Four new formations of Early Cambrian to Middle Ordovician age have been mapped in the Eagle region. Three of the formations, the Funnel Creek Limestone and Adams Argillite of Early Cambrian age and the Hillard Limestone of Early Cambrian to Early Ordovician age, are thought to have been deposited in a predominantly turbulent marine basin, and the fourth, the Jones Ridge Limestone of Early Cambrian to Middle or Late Ordovician age, is thought to have been deposited on a shoal or reef.

The rapid changes in facies, the possibility of reeflike sedimentation, and the occurrence of bitumen and other organic matter in the rocks make the lower Paleozoic sequence attractive for petroleum exploration. Large anticlines nearby (Brabb and Churkin, 1964) could contain these sequences at moderate depth, capped by relatively impermeable rocks. Inasmuch as none of these structural features have been tested, their petroleum potential is unknown.

\section{LOWER PALEOZOIC FOSSIL COLLECTIONS FROM EAST-CENTRAL ALASKA}

Known Cambrian and Lower Ordovician fossil collections from east-central Alaska are listed below, except those colleoted by L. D. Burling in 1913. Precise coordinates for collections listed in previously published reports are given here for the first time. Collections in the Eagle D-1 quadrangle and adjoining area in Canada are shown on a map by Brabb and Churkin (1965). Age determinations are by A. R. Palmer, unless otherwise noted.

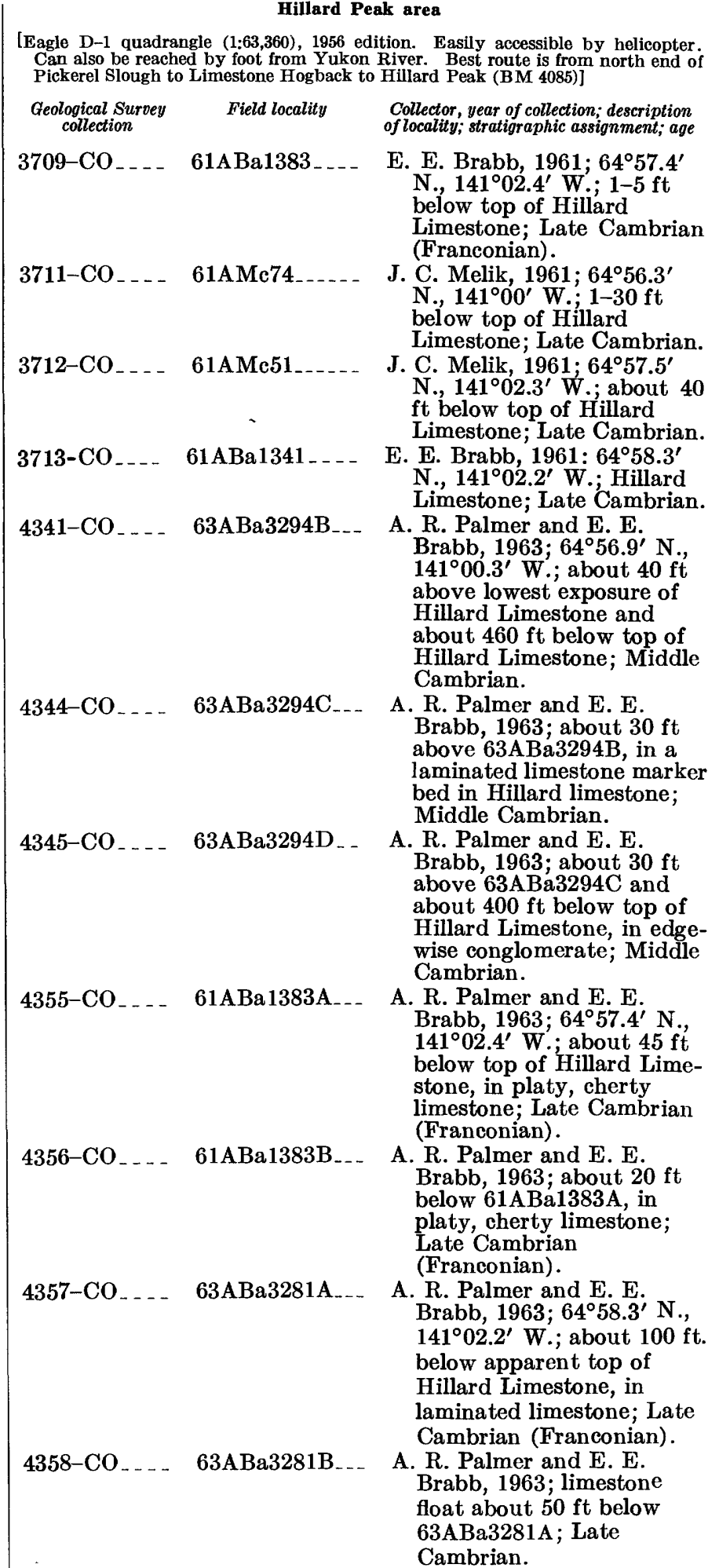

[Eagle D-1 quadrangle $(1: 63,360)$, 1956 edition. Easily accessible by helicopter Can also be reached by foot from Yukon River. Best route is from north end of
Pickerel Slough to Limestone Hogback to Hillard Peak (BM 4085)] Field locality

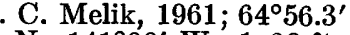
., $141^{\circ} 00^{\prime} \mathrm{W}$.; 1-30 ft Limestone; Late Cambrian. N., $141^{\circ} 02.3^{\prime} \mathrm{W}$.; about 40 ft below top of Hillard Limestone; Late Cambrian. N., $141^{\circ} 02.2^{\prime} \mathrm{W}$.; Hillard Limestone; Late Cambrian. $141^{\circ} 00.3^{\prime} \mathrm{W}$; ; about $40 \mathrm{ft}$ above lowest exposure of Hillard Limestone and Hillard Limestone. Cambrian.

R. Palmer and E. laminated limestone marker bed in Hillard limestone; Middle Cambrian. . ave $63 \mathrm{ABa} 3294 \mathrm{C}$ and about $400 \mathrm{ft}$ below top of wise conglomerate; Middle Cambrian. $141^{\circ} 024^{\prime} \mathrm{W}^{\prime}$; about $45 \mathrm{ft}$ below top of Hillard Limestone, in platy, cherty limestone; Late Cambrian (Franconian) below $61 \mathrm{ABa} 1383 \mathrm{~A}$, in platy, cherty limestone Late Cambrian (Franconian).

R. Palmer and Rabb, $1963 ; 6458.3^{\prime} \mathrm{N}$. below apparent top of Hillard Limestone, in laminated limestone; Late Cambrian (Franconian) Brabb, 1963; limestone 63ABa3281A; Late Cambrian. 


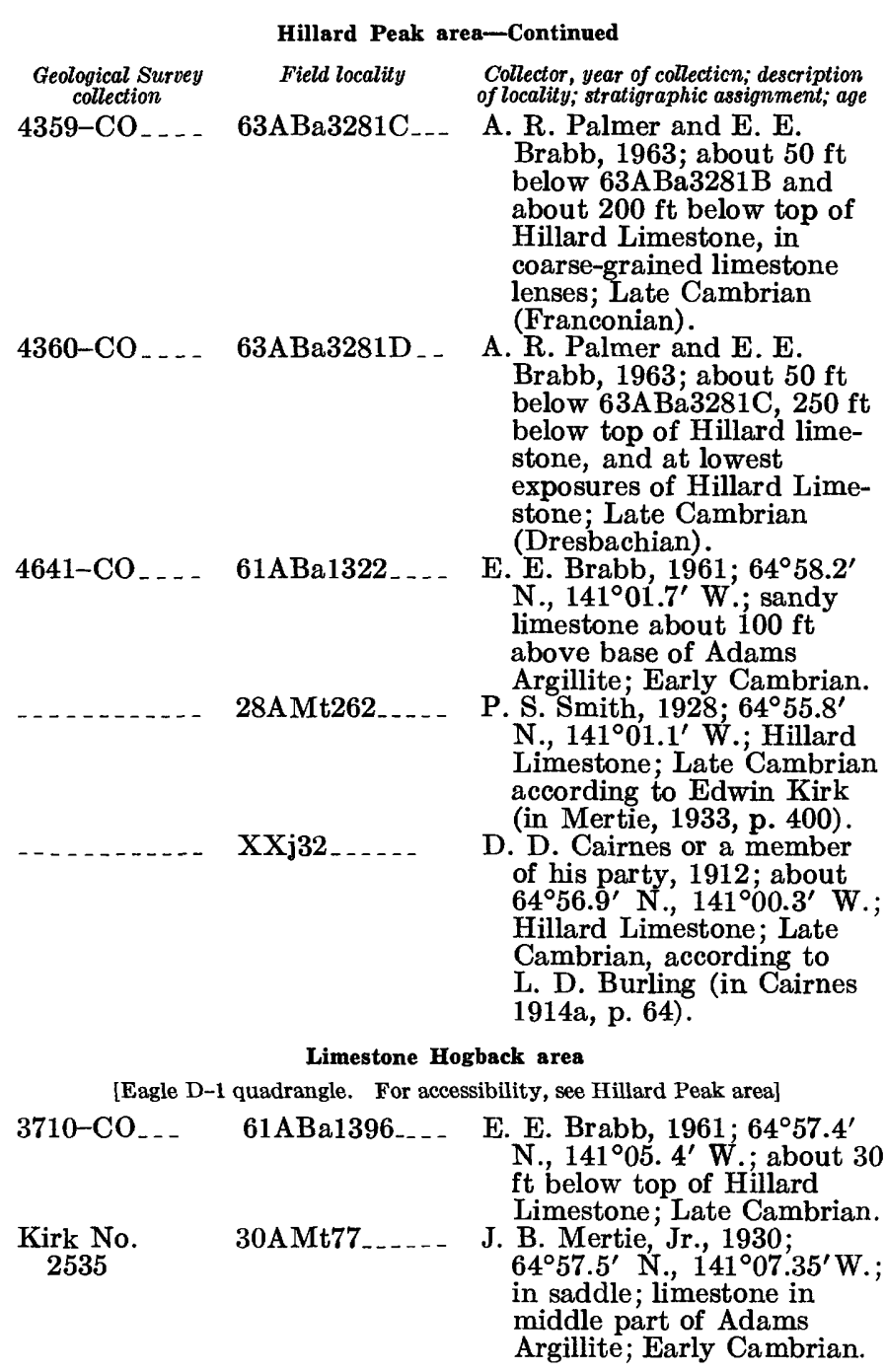

Yukon River area

[Eagle D-1 quadrangle. Not easily accessible by helicopter. Can be reached from [Eagle D-1 quadrangle. Not easily accessible by helicop
heliport near Adams Peak. Easily accessible by boat] 4295- $\mathrm{CO}$ $60 \mathrm{ABa} 222$

E. E. Brabb, $1960 ; 64^{\circ} 57.5^{\prime}$ N., $141^{\circ} 10.8^{\prime}$ W.; north bank of Yukon River at base of resistant limestone boulder conglomerate rib, probably a limestone bed within Adams Argillite but possibly Hillard Limestone; Early Cambrian. Locality recollected in 1963 by A. R. Palmer and E. E. Brabb.

28AMt263_... . J. B. Mertie, Jr., 1928; probably the same locality as 60ABa222; Middle Cambrian, according to Edwin Kirk (in Mertie, 1933 , p. 398) but contains archaeocyathids that may be Early Cambrian.

\begin{tabular}{|c|c|c|}
\hline $\begin{array}{l}\text { Geological Survey } \\
\text { collection }\end{array}$ & Field locality & $\begin{array}{l}\text { Collector, year of collection; description } \\
\text { of locality; stratigraphic assignment; age }\end{array}$ \\
\hline $4298-\mathrm{CO}_{-} \ldots$ & $60 \mathrm{ABa} 222 \mathrm{~F}$ & $\begin{array}{l}\text { Michael Churkin, Jr., and } \\
\text { E. E. Brabb, 1963; same } \\
\text { locality as 60ABa222 but } \\
\text { about } 100 \mathrm{ft} \text { above river; } \\
\text { apparently the same bed } \\
\text { as } 60 \mathrm{ABa} 222 \text {, but possibly } \\
\text { as much as } 20 \mathrm{ft} \text { strati- } \\
\text { graphically below, in } \\
\text { limestone edgewise } \\
\text { conglomerate; Early } \\
\text { Cambrian. }\end{array}$ \\
\hline $4298-\mathrm{CO}_{-} \ldots$ & $60 \mathrm{ABa} 222 \mathrm{G}_{\ldots}$ & $\begin{array}{l}\text { E. E. Brabb, 1963; same } \\
\text { locality as } 60 \mathrm{ABa} 222 \mathrm{~F} \\
\text { about } 5 \text { ft above } \\
60 \mathrm{ABa} 22 \mathrm{~F} \text {, in richly } \\
\text { fossiliferous limestone; } \\
\text { Early Cambrian. }\end{array}$ \\
\hline 4296-CO__ & 60ABa222GA & 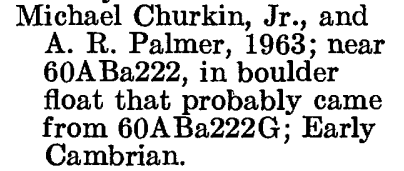 \\
\hline
\end{tabular}

Not collected_. 60ABa222H _ _ $\quad$ A. R. Palmer, 1963; 64 $57.4^{\prime}$ N., $141^{\circ} 11^{\prime}$ W.; resistant oolitic limestone boulder conglomerate knob on north bank of Yukon River, Hillard Limestone, about $25 \mathrm{ft}$ below top of oolitic limestone and limestone boulder conglomerate unit; trilobites and brachiopods observed in boulders; archaeocyathid observed in what appeared to be oolitic limestone matrix; Early Cambrian.

4330-CO _._. 60ABa222J _... A. R. Palmer, 1963; about 50 ft downstream from $60 \mathrm{ABa} 222 \mathrm{H}$, about $5 \mathrm{ft}$ below top of oolitic lime. stone unit within Hillard Limestone; Middle Cambrian.

Not collected_ 63ABa3151B___ E. E. Brabb, 1963; about 25 $\mathrm{ft}$ above $60 \mathrm{ABa222J}$, in dark-gray laminated limestone and shale unit within Hillard Limestone; Cam brian(?).

Adams Peak area

[Eagle D-1 quadrangle. Heliport at top of limessone slump(?) block, about 2,000 ft south of Adams Peak (BM 2814). Can also be reached by foot from Yukon River] 477-CO_ _. _ 38AMt29_... _ J. B. Mertie, Jr., 1938; about $64^{\circ} 58^{\prime}$ N., $141^{\circ} 11^{\prime}$ W.; altitude about $2,635 \mathrm{ft}$, in fine-grained limestone; Hillard Limestone; Late Cambrian.

478-CO _. _ _ 38AMt30 _... B. Mertie, Jr., 1938; about $64^{\circ} 58^{\prime} \mathrm{N} ., 141^{\circ} 11^{\prime} \mathrm{W}$. altitude about $2,515 \mathrm{ft}$, in limestone (edgewise?) conglomerate; Hillard Limestone; Middle or Late Cambrian. 


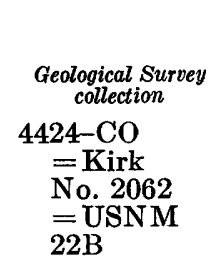

Adams Peak area-Continued

Field locality

25AMt148

Collector, year of collection; description
of locality; stratigraphic assignment; age

J. B. Mertie, Jr., 1925; abou ${ }^{\mathrm{t}}$ $64^{\circ} 58.2^{\prime} \mathrm{N} ., 141^{\circ} 11.1^{\prime} \mathrm{W}$.; altitude about $2,200 \mathrm{ft}$, limestone (edgewise?) conglomerate float in talus pile, possibly a composite collection, probably Hil. lard Limestone; Middle Cambrian.

Kirk No.

30AW13.

A. E. Waters, Jr., 1930; same talus pile as 25AMt148, but fossils from oolitic limestone, possibly a com. posite collection; probably Hillard Limestone; Early Cambrian.

3715-CO___ 61AMc911_...

J. C. Melik, $1961 ; 64^{\circ} 58.2^{\prime} \mathrm{N}$. $141^{\circ} 11.7^{\prime} \mathrm{W}$.; about 2,000 ft southwest of Adams Peak (BM 2814), a few feet stratigraphically above a boulder conglomerate; Hillard Limestone; Middle Cambrian.

3716-CO____ 61AMc931____ J. C. Melik, 1961; 645ㅇ' N., $141^{\circ} 11^{\prime} \mathrm{W}$.; limestone float; Hillard Limestone; Middle or Late Cambrian.

4337-CO_ _ _ 63ABa3191___ A. R. Palmer and E. E. Brabb, 1963; $64^{\circ} 58.2^{\prime} \mathrm{N}$., $141^{\circ} 11.5^{\prime} \mathrm{W}$.; at east edge of cliff, near base, bedded limestone about $20 \mathrm{ft}$ above boulder conglomerate; Hillard Limestone; Middle Cambrian.

4338-CO _ _ - 63ABa3191A__ $\quad$ A. R. Palmer and E. E. Brabb, 1963; about $100 \mathrm{ft}$ west of $70 \mathrm{ft}$ stratigraphically below $63 \mathrm{ABa} 3191$, from boulders within a boulder conglomerate; Hil lard Limestone; Early Cambrian.

4351-CO_ _ _ 63ABa3181_._. A. R. Palmer and E. E Brabb, 1963; 64 $58.2^{\prime} \mathrm{N}$. $141^{\circ} 11.2^{\prime}$ W.; about $10 \mathrm{ft}$ below top of limestone cliff and top of Hillard Limestone; Late Cambrian.

4352-CO_._. 63ABa3181C_._ A. R. Palmer, 1963; about 30 ft below 63ABa3181; Hillard Limestone; Iate Cambrian.

Ridge and flatiron southwest of Adams Peak

[Eagle D-1 quadrangle. For accessibility, see Adams Peak area]

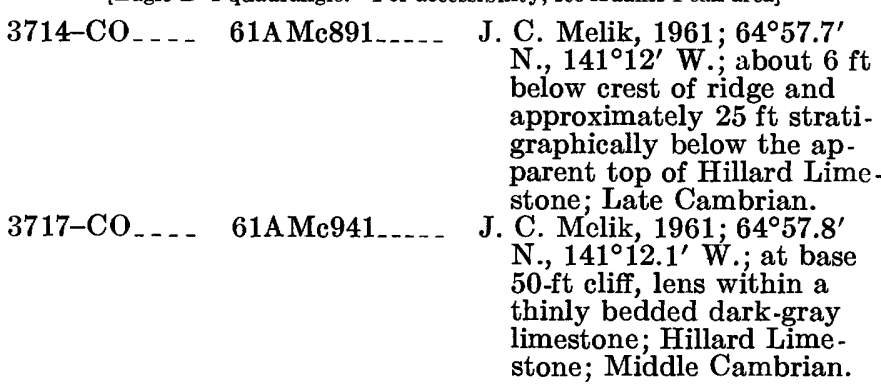

Ridge and flatiron southwest of Adams Peak-Continued

$\begin{array}{lc}\begin{array}{c}\text { Geological Survey } \\ \text { collection }\end{array} & \text { Field locality } \\ \text { 3718-CO____- } & \text { 61AMc941A }\end{array}$

Collector, year of collection; description of locality; stratigraphic assignment; age

J. C. Melik, 1961; about 100 ft north and uphill from 61AMc941, and evidently a few feet stratigraphically lower; fine-grained mottled gray limestone lens; Hillard Limestone; Middle Cambrian.

$3832-\mathrm{CO}_{\ldots} \ldots \quad 62 \mathrm{ABa} 2801 \ldots$ E. E. Brabb, $1962 ; 64^{\circ} 57.6^{\prime}$ N., $141^{\circ} 11.7^{\prime}$ W.; in central part of flatiron, upper most exposures of lime. stone; Hillard Limestone; Middle Cambrian.

$4332-\mathrm{CO} \ldots \quad 61 \mathrm{ABa} 2053$

A. R. Palmer and E. E. Brabb $1963 ; 64^{\circ} 57.6^{\prime} \mathrm{N} ., 141^{\circ} 11.7^{\prime}$ W.; at east edge of flatiron; uppermost exposures of limestone conglomerate and oolitic limestone; Hillard Limestone; Middle Cambrian.

4333-CO__._ 63ABa3171___ A. R. Palmer and E. E. Brabb, 1963; 64 ${ }^{\circ} 58.1^{\prime} \mathrm{N}$. $141^{\circ} 12.2^{\prime} \mathrm{W}$.; about $35 \mathrm{ft}$ below top of limestone cliff, from continuous bed of limestone within a lime. stone boulder conglomerate unit; Hillard Limestone; Early Cambrian.

4334-CO_ _ _ 63ABa3171A

A. R. Palmer, 1963; in bedded limestone about $20 \mathrm{ft}$ stratigraphically above 63ABa3171; Hillard Limestone; Early Cam. brian.

4335-CO_ _ _ 63ABa3171B

A. R. Palmer, 1963; in boulder within limestone boulder conglomerate a few inches below 63ABa3171; Hillard Limestone; Early Cambrian.

4347-CO___ 63ABa3172A__ A. R. Palmer, 1963; a few feet stratigraphically below $63 \mathrm{ABa3} 172$.

4348-CO _ _ 63ABa3172 $\ldots$

A. R. Palmer, $1963 ; 64^{\circ} 57.9^{\prime}$ N., $141^{\circ} 12.2^{\prime}$ W.; at base of limestone cliff, a few inches below a pisolitic limestone bed, in slabby limestone; Hillard Limestone; Middle Cambrian.

4349-CO _ _ _ 63ABa3161 _ _ $\quad$ A. R. Palmer and E. E. Brabb, 1963; same locality as 61AMc891 from a continuous bed of platy limestone; Hillard Limestone; Late Cambrian.

4350-CO_ _. 63ABa3161A._. E. E. Brabb, 1963; about 15 ft stratigraphically above $63 \mathrm{ABa} 3161$ and $10 \mathrm{ft}$ below apparent top of Hillard Limestone, in limestone edgewise conglomerate; Late Cambrian. 
Tatonduk River area

[Charley River A-1 quadrangle (1:63,360), 1956 edition. Not easily accessible by helicopter Marginal heliport established on ridge about 1 mile northeast of mouth of Thicket Creek. Best access is by boat 2-3 days after a heavy rain. Boat charter service available at Eagle. Tatonduk River may not be accessible when water is low]

Geological Survey $\quad$ Field locality collection $61 \mathrm{ABa} 2033$

4299-CO

Collector, year of collection; description of locality; stratigraphic assignment; age

E. E. Brabb, $1961 ; 65^{\circ} 014^{\prime}$

N., $141^{\circ} 12^{\prime}$ W.; north valley slope of Tatonduk River, about $75 \mathrm{ft}$ above river level; massive gray limestone about $10 \mathrm{ft}$ thick; Adams Argillite;

$\begin{array}{ll}\underset{2941}{\text { Kirk No. }} & \text { 30AW62 } \\ \text { Kirk No. } & \text { 30AW60 } \\ 2539 & \end{array}$

A. E. Waters, Jr., 1930; same locality as 61ABa2033; Early Cambrian.

A. E. Waters, Jr., 1930; about $65^{\circ} 01.8^{\prime} \mathrm{N}$ $141^{\circ} 12^{\prime} \mathrm{W}$.; altitude about $2,000 \mathrm{ft}$, on small knoll, float pieces of limestone; probably Adams Argillite; Early Cambrian.

30AW61

A. E. Waters, Jr., 1930; float collection near 30A W60; Late Cambrian, according to Edwin Kirk (in Mertie, 1933, p. 400).

Kirk No.

30Mt77 _..... 2535.

J. B. Mertie, Jr., 1930; possibly the same locality as 61ABa2033; Early Cambrian.

4302-CO_... 60ABa131B

4303-CO _. . 60ABa131A

A. R. Palmer and E. E. Brabb, 1963; 65 $01.3^{\prime} \mathrm{N}$. $141^{\circ} 12.2^{\prime}$ W.; north bank of Tatonduk River, in basal bed of Hillard Limestone; fossils from limestone boulder at base of limestone boulder conglomerate; conglomerate is resistant and forms ledge that protrudes into Tatonduk River; Early Cambrian.

A. R. Palmer and E. E. Brabb, 1963; about $90 \mathrm{ft}$ stratigraphically above $60 \mathrm{ABa} 131 \mathrm{~B}$ and at the base of a second boulder conglomerate that also protrudes into the Tatonduk River; fossils apparently were in matrix of conglomerate; Hillard Limestone; Middle Cambrian.

4304-CO_ _. 60ABa131EA _ A. R. Palmer and E. E. Brabb, 1963; about $65 \mathrm{ft}$ above 60ABa131A and 155 ft above base of Hillard Limestone; from bedded, sandy limestone; Middle Cambrian.

4308-CO _. - 60ABa131FA_- A. R. Palmer and E. E. Brabb, 1963; about $35 \mathrm{ft}$ above 60ABa131EA and $190 \mathrm{ft}$ above base of Hillard Limestone; fossils from calcareous concretions in shale; Middle Cambrian.

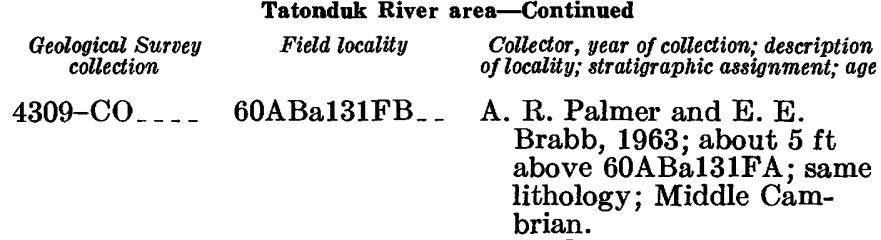

4310-CO__ _ 60ABa131H _ - A. R. Palmer and E. E. Brabb, 1963; about $30 \mathrm{ft}$ above $60 \mathrm{ABa} 131 \mathrm{FB}$ and 225

ft above base of Hillard Limestone; from graded limestone bed; Middle Cambrian.

4325-CO___ 60ABa131JA__- A. R. Palmer and E. E. Brabb, 1963; about $55 \mathrm{ft}$ above $60 \mathrm{ABa} 131 \mathrm{H}$, from thinly bedded limestone Hillard Limestone; Middle Cambrian.

4326-CO___ 60ABa131JB_- A. R. Palmer and E. E. Brabb, 1963; about 2 ft above $60 \mathrm{ABa131JA}$ Hillard Limestone; Middle Cambrian.

4327-CO__ _ $60 \mathrm{ABa} 131 \mathrm{~K} \ldots$

A. R. Palmer and E. E. Brabb, 1963; about $12 \mathrm{ft}$ above 60ABa131JB and $295 \mathrm{ft}$ above base of Hillard Limestone; from thin-bedded limestone interbedded with black chert; Middle or Late Cambrian.

Not collected_ 60ABa131LB - - A. R. Palmer and E. E. Brabb, 1963; about $50 \mathrm{ft}$ above $60 \mathrm{ABa} 131 \mathrm{~K}$ and 15 ft below the faulted (?) contact between Hillard Limestone and limestonechert breccia of Road River Formation; brachiopods from thin shale bed interbedded with limestone at north edge of Tatonduk River; age uncertain.

4339-CO _.. 63AGs13 . . . D. L. Giles, $1963 ; 65^{\circ} 01.3^{\prime}$ N., $141^{\circ} 12.2^{\prime}$ W., north valley slope of Tatonduk River, about $300 \mathrm{ft}$ above river, along strike of beds at $61 \mathrm{ABa131 \textrm {A }}$; fossils from bedded limestone about $90 \mathrm{ft}$ above base of Hillard Limestone; Middle Cambrian.

4340-CO_ _ _ 63ACn1492 _ _ _ Michael Churkin, Jr., 1963 same locality as 63 AGs13, a few feet stratigraphically higher, from matrix of limestone boulder conglomerate; Hillard Limestone; Middle Cambrian.

4353-CO _ _ $63 \mathrm{ACn} 1506 \ldots$
Michael Churkin, Jr., 1963 $65^{\circ} 01.5^{\prime}$ N., $141^{\circ} 12.1^{\prime} \mathrm{W}$.; north valley slope of Tatonduk-River, about 800 ft above river level, at top of 100-ft limestone cliff; fossils from uppermost bed of Hillard Limestone; Early Ordovician. 


\section{Montauk Bluff area}

[Charley River A-1 quadrangle. Easily accessible by helicopter. Can also be reached by a difficult hike from Yukon River up unnamed creek from NW $1_{4}$ sec. 11, T. $3 \mathrm{~N}$., R. $31 \mathrm{E}$., to center of sec. $35, T$. 4 N., R. 31 E., and then east along ridge to NW1/4 sec. 31 , T. 4 N., R. 32 E.]

Geological Survey

collection

4346-CO

Field locality

$63 \mathrm{ABa3373}$.
Collector, year of collection; description of locality; stratigraphic assignment; age

A. R. Palmer and E. E.

Brabb, 1963; 65ㅇ․ $08.1^{\prime} \mathrm{N}$., $141^{\circ} 19.4^{\prime} \mathrm{W}$.; near base of north-facing limestone cliff, about $20 \mathrm{ft}$ stratigraphically above the lowest exposure of Hillard Limestone; fossils from bed of medium-grained limestone; Middle Cambrian.

4379-CO_ _ _ 63ABa3373A__ $\quad$ A. R. Palmer and E. E. Brabb, 1963; about $200 \mathrm{ft}$ above $63 \mathrm{ABa3373}$, at top of cliff, in uppermost exposures of Hillard Limestone; from platy, finegrained limestone; Late Cambrian.

\section{Hard Luck Creek area}

[Charley River A-1 quadrangle. Easily accessible by helicopter. Could also be reached by a long, arduous foot traverse from Yukon River. Hard Luck Creek cannot be traversed after heavy ram]

4376- $\mathrm{CO} \ldots \ldots$. . $63 \mathrm{ABa} 3611 \ldots$

E. E. Brabb and Michael Churkin, Jr., 1963; $65^{\circ} 11.6^{\prime}$ N., $141^{\circ} 19.4^{\prime}$ W.; small outcrop on west bank of Hard Luck Creek, across from cliff exposures of Hillard Limestone, about $100 \mathrm{ft}$ below top of Hillard Limestone; fossils from bed of coarsegrained limestone; Late Cambrian (Dresbachian).

4378-CO _ _ _ 63ACn1751 _. _ _ Michael Churkin, Jr., 1963; $65^{\circ} 11.9^{\prime}$ N., $141^{\circ} 21^{\prime}$ W.; on spur of ridge about $1,500 \mathrm{ft}$ west of Hard Luck Creek; fossils from thick-bedded, oolitic, and partly conglomeratic Hillard Limestone; about $75 \mathrm{ft}$ of the formation is exposed; Middle Cambrian.

4382-CO _ _ _ 63ACn1932 _. _ $\quad$ Michael Churkin, Jr., 1963; $65^{\circ} 11.8^{\prime}$ N., $141^{\circ} 25.5^{\prime}$ W. on resistant limestone knoll; fossils from mediumbedded, oolitic, and partly conglomeratic Hillard Limestone; about $200 \mathrm{ft}$ of the formation is exposed; structure complex in this area and at 63ACn1751; Middle Cambrian.

Jones Ridge-Squaw Mountain area

[Charley River A-1 quadrangle. Easily accessible by helicopter. Can also be reached by a long, arduous foot traverse from Tatonduk River]

D1071-CO_-_ RJR4-62_. _. _ R. J. Ross, Jr., 1962 . $65^{\circ} 06.2^{\prime} \mathrm{N}$., $141^{\circ} 02.1^{\prime} \mathrm{W}$.; coarse-grained bioclastic limestone at base of cliff evidently the uppermost exposure of the upper member of the Jones Ridge Limestone; Middle or Late Ordovician, according to Ross.

\begin{tabular}{|c|c|c|}
\hline \multicolumn{3}{|c|}{ Jones Ridge-Squaw Mountain area-Continued } \\
\hline $\begin{array}{l}\text { Geological Survey } \\
\text { collection }\end{array}$ & Field locality & $\begin{array}{l}\text { Collector, year of collection; description } \\
\text { of locality; stratigraphic assignment; age }\end{array}$ \\
\hline D1072-CO_-- & RJR5-62_- & $\begin{array}{l}\text { R. J. Ross, Jr., } 1962 ; \\
65^{\circ} 06.0^{\prime} \text { N., } 141^{\circ} 02.5^{\prime} \mathrm{W} . ; \\
\text { coarse-grained bioclastic } \\
\text { limestone talus, appar- } \\
\text { ently near base of upper } \\
\text { member of Jones Ridge } \\
\text { Limestone; Middle or } \\
\text { Late Ordovician, accord- } \\
\text { ing to Ross. }\end{array}$ \\
\hline D-1077-CO_- & $62 \mathrm{ABa} 2812^{\ldots} \ldots$ & $\begin{array}{l}\text { E. E. Brabb, } 1962 ; 65^{\circ} 04.3^{\prime} \\
\text { N., } 141^{\circ} 02.7^{\prime} \text { W.; form } \\
\text { extensively sheared and } \\
\text { faulted Jones Ridge } \\
\text { Limestone; Early Ordo- } \\
\text { vician, according to Ross. }\end{array}$ \\
\hline 2536-SD__._- & 30AMt145 .... & $\begin{array}{l}\text { J. B. Mertie, Jr., } 1930 \text {; about } \\
65^{\circ} 06^{\prime} \text { N., } 141^{\circ} 02.5^{\prime} \text { W.; } \\
\text { from talus on northeast } \\
\text { valley slope of Hard Luck } \\
\text { Creek; some fossils are } \\
\text { apparently from lower mem- } \\
\text { ber of Jones Ridge Lime- } \\
\text { stone and some evidently } \\
\text { from upper member; fauna } \\
\text { mixed, according to Ross, } \\
\text { and contains fossils of Early } \\
\text { and Middle or Late Ordo- } \\
\text { vician age. }\end{array}$ \\
\hline $3833-\mathrm{CO}_{-}--$ & RJR7-62_ $\ldots$ & $\begin{array}{l}\text { R. J. Ross, Jr., } 1962 ; 65^{\circ} 06.1^{\prime} \\
\text { N., } 141^{\circ} 02.8^{\prime} \text { W.; along } \\
\text { upper part of Hard Luck } \\
\text { Creek; fine-grained lime- } \\
\text { stone, lower member of } \\
\text { Jones Ridge Limestone; } \\
\text { Late Cambrain (Trempel- } \\
\text { eauan). }\end{array}$ \\
\hline
\end{tabular}

3834-CO__. - RJR8-62_... R. J. Ross, Jr., 1962; about $20 \mathrm{ft}$ stratigraphically below RJR7-62; from fine- to medium-grained limestone, lower member of Jones Ridge Limestone; Late Cambrain (Trempeleauan).

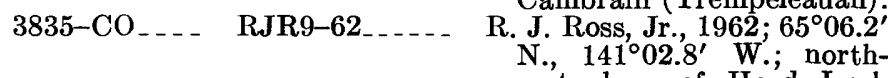
east slope of Hard Iuck Creek; very fine grained limestone float, probably from lower member of Jones Ridge Limestone; Late Cambrain (Trempeleauan).

3836-CO_ _. _ RJR10-62 _. _ _ R. J. Ross, Jr., $1962 ; 65^{\circ} 06.3^{\prime}$ N., $141^{\circ} 02.9^{\prime}$ W.; from massive limestone cliff on northeast side of Hard Luck Creek; some fossils also from talus; mediumgrained limestone, probably lower member of Jones Ridge Limestone, 500-1,500 ft below top of member; Late(?) Cambrain.

3837-CO, RJR6-62_... R. J. Ross, Jr., 1962; $65^{\circ} 06^{\prime}$ N., $141^{\circ} 02.7^{\prime}$ W.; from very fine grained limestone, probably lower member of Jones Ridge Limestone: Late Cambrian (Trempeleauan).

4300-CO__. 63ABa3352 _.. A. R. Palmer and E. E. Brabb, 1963; $65^{\circ} 04.6^{\prime} \mathrm{N}$. $141^{\circ} 06.4^{\prime}$ W.; ridge crest; stratigraphic relation to 63ABa3351 uncertain;lower member of Jones Ridge Limestone; Early Cambrian. 


\begin{tabular}{|c|c|c|}
\hline \multicolumn{3}{|c|}{ Jones Ridge-Squaw Mountain area-Continued } \\
\hline $\begin{array}{l}\text { Geological Survey } \\
\text { collection }\end{array}$ & Field locality & $\begin{array}{l}\text { Collector, year of collection; description } \\
\text { of locality; stratigraphic assignment; age }\end{array}$ \\
\hline $4301-\mathrm{CO}_{-} \ldots$ & $63 \mathrm{ABa} 3381$ & $\begin{array}{l}\text { E. E. Brabb, } 1963 ; 65^{\circ} 05.3^{\prime} \\
\text { N., } 141^{\circ} 07.3^{\prime} \text { W.; about } \\
500 \mathrm{ft} \text { above base of lower } \\
\text { member of Jones Ridge } \\
\text { Limestone; Early Cam- } \\
\text { brian. }\end{array}$ \\
\hline $4361-\mathrm{CO}_{-} \ldots$ & $63 \mathrm{ABa} 3332$ & $\begin{array}{l}\text { A. R. Palmer and E. E. } \\
\text { Brabb, } 1963 ; 65^{\circ} 06.5^{\prime} \text { N., } \\
141^{\circ} 01^{\prime} \text { W.; south slope of } \\
\text { Jones Ridge, altitude about } \\
4,000 \mathrm{ft} \text {; from massive, very } \\
\text { fine grained limestone, } \\
\text { about } 600 \mathrm{ft} \text { below top of } \\
\text { lower member of Jones } \\
\text { Ridge Limestone; Late } \\
\text { Cambrian (Dresbachian). }\end{array}$ \\
\hline $4362-\mathrm{CO}_{-} \ldots$ & $63 \mathrm{ABa3332A}$ & $\begin{array}{l}\text { A. R. Palmer and E. E. } \\
\text { Brabb, 1963; about } 100 \mathrm{ft} \\
\text { stratigraphically above } \\
\text { 63ABa3332; Late Cam- } \\
\text { brian (Trempeleauan). }\end{array}$ \\
\hline $4363-\mathrm{CO}_{-} \ldots$ & 63ABa3332B & $\begin{array}{l}\text { A. R. Palmer and E. E. } \\
\text { Brabb, 1963; about } 200 \mathrm{ft} \\
\text { above 63ABa3332A; Late } \\
\text { Cambrian (Trempeleauan). }\end{array}$ \\
\hline $4364-\mathrm{CO}_{-} \ldots$ & $63 \mathrm{ABa3333} \ldots$ & $\begin{array}{l}\text { A. R. Palmer and E. E. } \\
\text { Brabb, } 1963 ; 65^{\circ} 06.3^{\prime} \mathrm{N} ., \\
141^{\circ} 01^{\prime} \text { W.; altitude about } \\
3,300 \mathrm{ft} \text {, south slope of } \\
\text { Jones Ridge; from coarse- } \\
\text { grained bioclastic limestone } \\
35-50 \mathrm{ft} \text { below top of upper } \\
\text { member of Jones Ridge } \\
\text { Limestone; Middle or Late } \\
\text { Ordovician (Caradocian), } \\
\text { according to R. J. Ross, Jr. }\end{array}$ \\
\hline $4365-\mathrm{CO}_{-}-\ldots$ & 63ABa3333A_.- & $\begin{array}{l}\text { E. E. Brabb and Michael } \\
\text { Churkin, Jr., 1963; same } \\
\text { locality as 63ABa3333 but } \\
12 \mathrm{ft} \text { below top of upper } \\
\text { member of Jones Ridge } \\
\text { Limestone; probably same } \\
\text { age as 63ABa3333, accord- } \\
\text { ing to R. J. Ross, Jr. }\end{array}$ \\
\hline $4366-\mathrm{CO} \ldots$ & 63ABa3333B & $\begin{array}{l}\text { E. E. Brabb and Michael } \\
\text { Churkin, Jr., } 1963 ; \text { about } \\
30 \mathrm{ft} \text { below } 63 \mathrm{ABa} 3333 \mathrm{~A} \\
\text { and about } 13 \mathrm{ft} \text { above base } \\
\text { of upper member of Jones } \\
\text { Ridge Limestone; probably } \\
\text { Middle Ordovician, accord- } \\
\text { ing to R. J. Ross, Jr. }\end{array}$ \\
\hline $4367-\mathrm{CO}$ & 63ABa3333D_- & $\begin{array}{l}\text { E. E. Brabb and Michael } \\
\text { Churkin, Jr., } 1963 ; \text { about } \\
70 \mathrm{ft} \text { below } 63 \mathrm{ABa} 333 \mathrm{D} \\
\text { and } 50 \mathrm{ft} \text { below top of lower } \\
\text { member of Jones Ridge } \\
\text { Limestone; Early Ordovi- } \\
\text { cian, according to R. J. } \\
\text { Ross, Jr. }\end{array}$ \\
\hline $4368-\mathrm{CO}_{-} \ldots$ & 63ABa3333E_..- & $\begin{array}{l}\text { E. E. Brabb and Michael } \\
\text { Churkin, Jr., } 1963 ; \text { about } 7 \\
\text { ft below } 63 \text { ABBa3333D and } \\
\text { about } 57 \mathrm{ft} \text { below top of } \\
\text { lower member of Jones } \\
\text { Ridge Limestone; Early } \\
\text { Ordovician, according to } \\
\text { R. J. Ross, Jr. }\end{array}$ \\
\hline $4369-\mathrm{CO}_{-} \ldots$ & $63 \mathrm{ABa3333F}$ & $\begin{array}{l}\text { E. E. Brabb and Michael } \\
\text { Churkin, Jr., 1963; about } \\
85 \mathrm{ft} \text { below 63ABa3333E } \\
\text { and } 145 \mathrm{ft} \text { below the top of } \\
\text { lower member of Jones } \\
\text { Ridge Limestone; Early } \\
\text { Ordovician, according to } \\
\text { R. J. Ross, Jr. }\end{array}$ \\
\hline
\end{tabular}

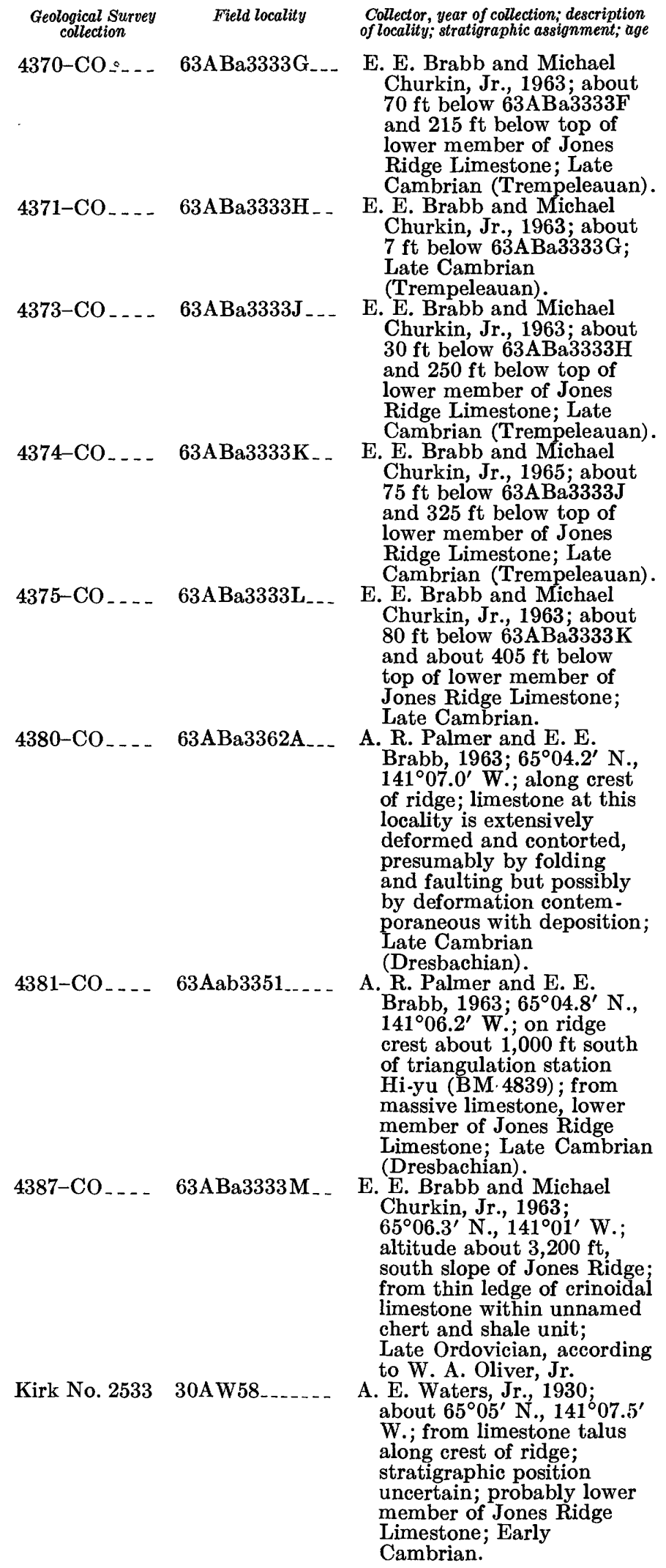

A. R. Palmer and E. E. Brabb, 1963; $65^{\circ} 04.2^{\prime} \mathrm{N}$., $141^{\circ} 07.0^{\prime} \mathrm{W}$.; along crest of ridge; limestone at this locality is extensively deformed and contorted, presumably by folding and faulting but possibly by deformation contem. poraneous with deposition; Late Cambrian (Dresbachian).

4381-CO_.__ 63Aab3351_... _ A. R. Palmer and E. E. Brabb, 1963; 65 $04.8^{\prime}$ N., $141^{\circ} 06.2^{\prime} \mathrm{W}$.; on ridge crest about $1,000 \mathrm{ft}$ south of triangulation station Hi-yu (BM. 4839); from massive limestone, lower member of Jones Ridge Limestone; Late Cambrian (Dresbachian)

4387-CO___ 63ABa3333M _ _ E. E. Brabb and Michael Churkin, Jr., 1963; $65^{\circ} 06.3^{\prime} \mathrm{N} ., 141^{\circ} 01^{\prime} \mathrm{W}$.; altitude about $3,200 \mathrm{ft}$, south slope of Jones Ridge; from thin ledge of crinoida limestone within unnamed chert and shale unit; Late Ordovician, according to W. A. Oliver, Jr.

Kirk No. 2533 30A W58 $\ldots . . . .$.

A. E. Waters, Jr., 1930; about $65^{\circ} 05^{\prime}$ N., $141^{\circ} 07.5^{\prime}$ W.; from limestone talus along crest of ridge; stratigraphic position uncertain; probably lower member of Jones Ridge Limestone; Early Cambrian. 


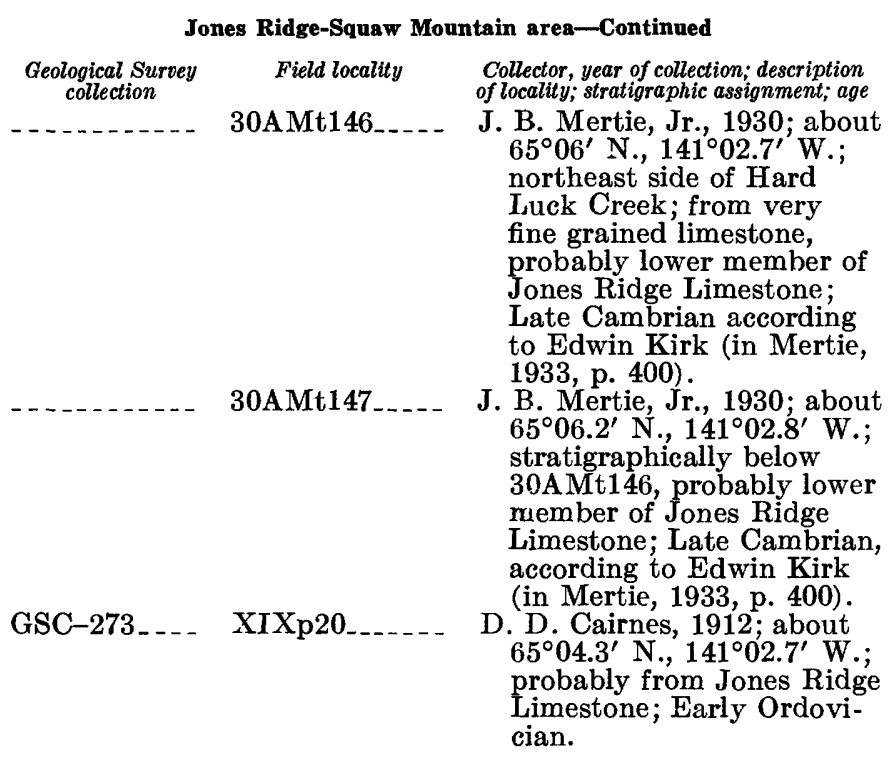

Extension of Jones Ridge-Squaw Mountain area in Canada

[Localities plotted from sheet 19 of the International Boundary Commission $(1: 62,500)$, 1914 ed., and from unpub. data]

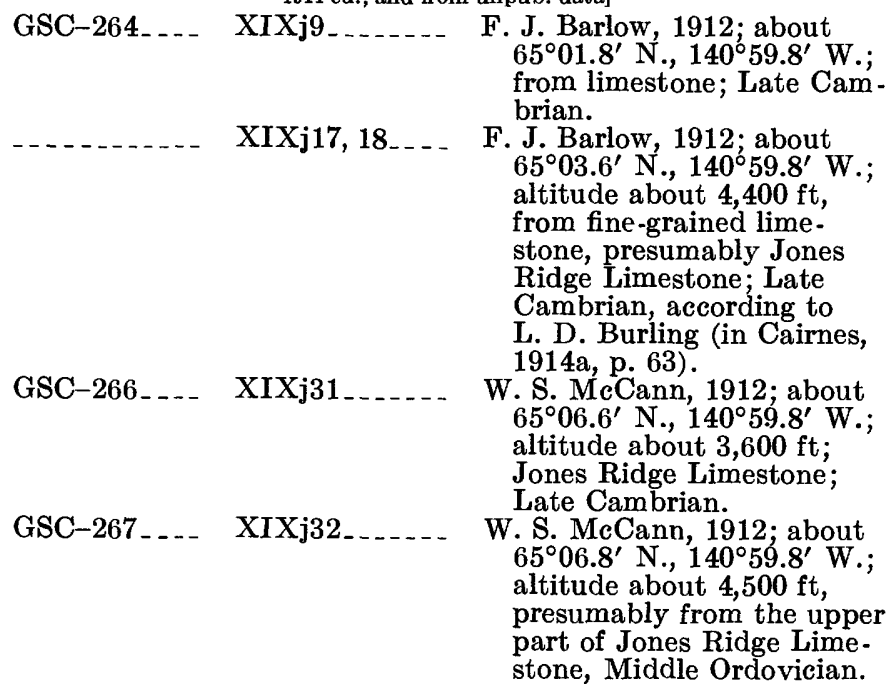

Extension of Hillard Peak area, in Canada

[Localities plotted from sheet 18 of International Boundary Commission (1:62,500, 1914 ed., and from unpub. data]

XXe39.

F. J. Barlow, 191\%; about $64^{\circ} 59.4^{\prime}$ N., $140^{\circ} 57^{\prime} \mathrm{W}$. probably on south valley slope of Tatonduk River, from thick-bedded limestone, probably Hillard Limestone; Late Cambrian according to L. D. Burling (in Cairnes, 1914a, p. 65).

GSC-278_... XXc29_..... _ F. J. Barlow, 1912; about $64^{\circ} 56.1^{\prime}$ N., $140^{\circ} 56.8^{\prime} \mathrm{W}$.; altitude about $2,900 \mathrm{ft}$ from limestone, probably Hillard Limestone; Late Cambrian.

GSC-282 ... . XXi34_..... F. J. Barlow, 1912; about $64^{\circ} 57.1^{\prime}$ N., $140^{\circ} 59.1^{\prime} \mathrm{W}$.; altitude about $3,000 \mathrm{ft}$, from limestone dipping $70^{\circ} \mathrm{NE}$., probably Hillard Limestone; Middle Cambrian.

\begin{tabular}{|c|c|c|}
\hline \multicolumn{3}{|c|}{ Extension of Hillard Peak area, in Canada-Continued } \\
\hline $\begin{array}{l}\text { Geological Survey } \\
\text { collection }\end{array}$ & Field locality & $\begin{array}{l}\text { Collector, year of collection; description } \\
\text { of locality; stratigraphic assignment; age }\end{array}$ \\
\hline $3505-\mathrm{CO}_{-} \ldots$ & $60 \mathrm{ABa} 71 \ldots$ & $\begin{array}{l}\text { E. E. Brabb and H. J. } \\
\text { Roepke, } 1960 ; 64^{\circ} 59.4^{\prime} \\
\text { N., } 140^{\circ} 59.1^{\prime} \text { W.; south } \\
\text { bank of Tatonduk River; } \\
\text { from upper part of } \\
\text { Hillard Limestone; Late } \\
\text { Cambrian. }\end{array}$ \\
\hline \multicolumn{3}{|c|}{ Miscellaneous localities } \\
\hline $5156-\mathrm{CO}_{-} \ldots$ & 60ABa184A__-- & $\begin{array}{l}\text { H. J. Roepke, R. N. } \\
\text { Passero, and E. E. Brabb, } \\
1960 ; \text { Charley River A-1 } \\
\text { quadrangle, } 65^{\circ} 00.3^{\prime} \text { N., } \\
141^{\circ} 02.2^{\prime} \text { W.; south bank } \\
\text { of Tatonduk River, about } \\
200 \text { ft downstream from } \\
\text { mouth of unnamed creek; } \\
\text { fossils from limestone; } \\
\text { stratigraphic position } \\
\text { uncertain; Early } \\
\text { Cambrian. }\end{array}$ \\
\hline $5158-\mathrm{CO}_{-} \ldots$ & $60 \mathrm{ABa} 203$ & $\begin{array}{l}\text { E. E. Brabb, 1960; Charley } \\
\text { River A-1 quadrangle, } \\
65^{\circ} 02.1^{\prime} \text { N., } 141^{\circ} 03.8^{\prime} \mathrm{W} . \\
\text { east bank of Funnel } \\
\text { Creek, extensively de- } \\
\text { formed grayish-black } \\
\text { bioclastic limestone; } \\
\text { Early Cambrian. }\end{array}$ \\
\hline $5159-\mathrm{CO}_{-} \ldots$ & $60 \mathrm{ABa} 204$ & $\begin{array}{l}\text { E. E. Brabb, 1960; Charley } \\
\text { River A-1 quadrangle, } \\
65^{\circ} 02.2^{\prime} \text { N., } 141^{\circ} 03.7^{\prime} \mathrm{W} . ; \\
\text { along Funnel Creek, } \\
\text { grayish-black limestone; } \\
\text { Early Cambrian. }\end{array}$ \\
\hline 5157-CO__- & $60 \mathrm{ABa} 206$ & $\begin{array}{l}\text { R. N. Passero and E. E. } \\
\text { Brabb, } 1960 \text {; Charley } \\
\text { River A-1 quadrangle, } \\
65^{\circ} 00.9^{\prime} \text { N., } 141^{\circ} 02.9^{\prime} \mathrm{W} . ; \\
\text { from limestone along } \\
\text { Funnel Creek; Early } \\
\text { Cambrian. }\end{array}$ \\
\hline$\frac{\text { Kirk No. }}{2528 .}$ & 30AMt136 & $\begin{array}{l}\text { J. B. Mertie, Jr., 1930; } \\
\text { probably same locality as } \\
\text { 60ABa206; Early } \\
\text { Cambrian. }\end{array}$ \\
\hline$\underset{2532 .}{\text { Kirk No. }}$ & 30AMt214 & $\begin{array}{l}\text { J. B. Mertie, Jr., } 1930 \text {; } \\
\text { Charley River A-1 } \\
\text { quadrangle, about } 65^{\circ} 04.1^{\prime} \\
\text { N., } 141^{\circ} 08.5^{\prime} \text { W.; from } \\
\text { limestone float; Early } \\
\text { Cambrian(?). }\end{array}$ \\
\hline $4377-\mathrm{CO}_{\ldots} \ldots$ & $63 \mathrm{ABa} 3523$ & $\begin{array}{l}\text { E. E. Brabb, } 1963 \text {; in } \\
\text { Canada east of Charley } \\
\text { River B-1 quadrangle, } \\
65^{\circ} 23.3^{\prime} \mathrm{N} ., 140^{\circ} 59.5^{\prime} \mathrm{W} . \text {; } \\
\text { from uppermost bed of } \\
30 \text {-ft-thick limestone } \\
\text { underlying and presum- } \\
\text { ably in fault contact with } \\
\text { limestone of Devonian } \\
\text { age and overlying dolomite } \\
\text { of unknown age; Late } \\
\text { Cambrian (Franconian). }\end{array}$ \\
\hline
\end{tabular}

Occurrences of Oldhamia in Alaska

[Age determinations by Churkin and Brabb (1965b)]

\begin{tabular}{|c|c|c|}
\hline $\mathrm{M}^{1024-\mathrm{CO}_{-}-}$ & $62 \mathrm{ACn} 851$ & $\begin{array}{l}\text { Michael Churkin, Jr., 1962; } \\
\text { Charley River B-2 quad- } \\
\text { rangle, } 65^{\circ} 20.2^{\prime} \mathrm{N} ., \\
141^{\circ} 46.0^{\prime} \mathrm{W} . ; \text { Adams } \\
\text { Argillite; probably Cam- } \\
\text { brian. }\end{array}$ \\
\hline
\end{tabular}




\begin{tabular}{|c|c|c|}
\hline \multicolumn{3}{|c|}{ Occurrences of Oldhamia in Alaska-Continued } \\
\hline $\begin{array}{l}\text { Geological Survey } \\
\text { collection }\end{array}$ & Field locality & $\begin{array}{l}\text { Collector, year of collection; description } \\
\text { of locality; stratigraphic assignment; age }\end{array}$ \\
\hline $\mathrm{M} 1025-\mathrm{CO}_{-}-$ & $62 \mathrm{ACn} 891 \ldots$ & $\begin{array}{l}\text { Michael Churkin, Jr., 1962; } \\
\text { Charley River B-2 quad- } \\
\text { rangle, } 65^{\circ} 20.0^{\prime} \text { N., } \\
141^{\circ} 45.7^{\prime} \text { W.; Adams } \\
\text { Argillite; probably Cam- } \\
\text { brian. }\end{array}$ \\
\hline M1026-CO _- & $62 \mathrm{ACn} 1081$ & $\begin{array}{l}\text { Michael Churkin, Jr., 1962; } \\
\text { Charley River B-2 quad- } \\
\text { rangle, } 65^{\circ} 19.4^{\prime} \text { N., } \\
141^{\circ} 50.3^{\prime} \text { W.; Adams } \\
\text { Argillite; probably Cam- } \\
\text { brian. }\end{array}$ \\
\hline $\mathrm{M}^{1027-\mathrm{CO}_{-}-}$ & $63 \mathrm{ACn} 2091$ & $\begin{array}{l}\text { Michael Churkin, Jr., 1963; } \\
\text { same locality as } 62 \mathrm{ACn}- \\
\text { 1081; probably Cambrian. }\end{array}$ \\
\hline $\mathrm{M} 1028-\mathrm{CO}_{-}-$ & $63 \mathrm{ACn} 2126$ & $\begin{array}{l}\text { Michael Churkin, Jr., 1963; } \\
\text { Charley River B-2 quad- } \\
\text { rangle, 65'19.7' N., } \\
1^{\circ} 41^{\circ} 43.4^{\prime} \text { W.; Adams } \\
\text { Argillite; probably Cam. } \\
\text { brian. }\end{array}$ \\
\hline $\mathrm{M} 1029-\mathrm{CO}_{-}$ & $63 \mathrm{ACn} 2212_{\ldots} \ldots$ & $\begin{array}{l}\text { Michael Churkin, Jr., 1963; } \\
\text { Charley River A-2 quad- } \\
\text { rangle, } 65^{\circ} 13.4^{\prime} \text { N., } \\
141^{\circ} 37.0^{\prime} \text { W.; Adams } \\
\text { Argillite; probably Cam- } \\
\text { brian. }\end{array}$ \\
\hline $\mathrm{M} 1030-\mathrm{CO}_{-}-$ & $63 \mathrm{AGs} 344 \mathrm{~B}$ & $\begin{array}{l}\text { D. L. Giles, 1963; Charley } \\
\text { River A-2 quadrangle, } \\
65^{\circ} 14.7^{\prime} \text { N., } 141^{\circ} 37.6^{\prime} \mathrm{W} \text {; } \\
\text { Adams Argillite; probably } \\
\text { Cambrian. }\end{array}$ \\
\hline ' & 21AMt152 & $\begin{array}{l}\text { J. B. Mertie, Jr., } 1921 \text {; } \\
\text { Livengood D-2 quad - } \\
\text { rangle, about } 65^{\circ} 54^{\prime} \text { N., } \\
147^{\circ} 44^{\prime} \text { W.; altitude } 3,000 \\
\text { ft, unnamed formation; } \\
\text { probably Cambrian. }\end{array}$ \\
\hline-- & KP0245. & $\begin{array}{l}\text { BP Exploration Co. (Alaska) } \\
\text { Inc., 1962; Circle C-3 } \\
\text { quadrangle, } 65^{\circ} 43^{\prime} \mathrm{N} ., \\
145^{\circ} 04.3^{\prime} \mathrm{W} . ; \text { from un- } \\
\text { named argillite and quart- } \\
\text { zite formation; probably } \\
\text { Cambrian. }\end{array}$ \\
\hline
\end{tabular}

\section{REFERENCES CITED}

Brabb, E. E., and Churkin, Michael, Jr., 1964, Preliminary geologic map of the Charley River quadrangle $(1: 250,000)$, east-central Alaska: U.S. Geol. Survey open-file report.

- 1965, Preliminary geologic map of the Eagle D-1 quadrangle $(1: 63,360)$, east-central Alaska: U.S. Geol. Survey open-file report.

Brooks, A. H., 1911, The Mount McKinley region, Alaska : U.S. Geol. Survey Prof. Paper 70, 234 p.

Brown, J. S., 1926, The Nixon Fork country and silver-lead prospects near Ruby: U.S. Geol. Survey Bull. 783-D, p. 97-150.

Buddington, A. F., and Chapin, Theodore, 1929, Geology and mineral deposits of southeastern Alaska: U.S. Geol. Survey Bull. 800, 398 p.
Cairnes, D. D., 1914a, The Yukon-Alaska international boundary, between Porcupine and Yukon Rivers: Canada Geol. Survey Mem. 67, 161 p., 16 pls.

- 1914b, Geological section along the Yukon-Alaska boundary line between Yukon and Porcupine Rivers: Geol. Soc. America Bull., v. 25, p. 179-204.

Churkin, Michael, Jr., and Brabb, E. E., 1965a, Ordovician, Silurian and Devonian biostratigraphy of east-central Alaska: Am. Assoc. Petroleum Geologists Bull., v. 49, no. 2, p. 172-185.

1965b, Occurrence and stratigraphic significance of oldhamia, a Cambrian trace fossil in east-central Alaska in Geological Survey research 1965: U.S. Geol. Survey Prof. Paper 525-D, p. D120-D124.

Douglas, R. J. W., and others, 1963, Geology and petroleum potentialities of northern Canada: Canada Geol. Survey Paper 63-31, $28 \mathrm{p}$.

Eakin, H. M., 1918, The Cosna-Nowitna region, Alaska: U.S. Geol. Survey Bull. 667, 54 p.

Goddard, E. N., chm., and others, 1948, Rock-color chart: Washington, Natl. Research Council (repub. by Geol. Soc. America, 1951), $6 \mathrm{p}$.

Green, L. H., and Roddick, J. A., 1962, Dawson, Larsen Creek, and Nash Creek map-areas, Yukon Territory: Canada Geol. Survey Paper 62-7, 20 p.

Kindle, E. M., 1908, Geologic reconnaissance of the Porcupine valley, Alaska : Geol. Soc. America Bull., v. 19, p. 315-338.

Mertie, J. B., Jr., 1930, Geology of the Eagle-Circle district, Alaska: U.S. Geol. Survey Bull. 816, 168 p.

- 1933, The Tatonduk-Nation district: U.S. Geol. Survey Bull. 836-E. p. 347-443.

- 1937, The Yukon-Tanana region, Alaska : U.S. Geol. Survey Bull. $872,276 \mathrm{p}$.

Okulitch, V. J., 1955, Archaeocyatha, in Moore, R. C., ed., Treatise on invertebrate paleontology. Part E, Archaeocyatha and Porifera : New York and Lawrence, Kans., Geol. Soc. America and Univ. Kansas Press, p. E1-E20.

1956, The Lower Cambrian of western Canada and Alaska, in Rodgers, John ed., El Sistema Cámbrico, su paleogeografia y el problema de su base-symposium, pt. 2 : Internat. Geol. Cong., 20th, Mexico City, 1956, p. 701-734.

Okulitch, V. J., and Greggs, R. G., 1958, Archaeocyathid localities in Washington, British Columbia and Yukon Territory: Jour. Paleontology, v. 32, no. 3, p. 617-623.

Ross, R. J., Jr., and Dutro, J. T., Jr., 1966, Silicified Ordovician brachiopods from east-central Alaska: Smithsonian Misc. Collns., v. 149, no. 7, 22 p., 3 pls.

Sainsbury, C. L., Previously undescribed Middle (?) Ordovician, Devonian(?), and Cretaceous rocks, White Mountain area, near McGrath, Alaska, in Geological Survey research 1965 : U.S. Geol. Survey Prof. Paper 525-C, p. C91-C95.

Steidtmann, Edward, and Cathcart, S. H., 1922, Geology of the York tin deposits, Alaska : U.S. Geol Survey Bull. 733, 130 p. 